\title{
Sapindaceae da Restinga da Marambaia, Rio de Janeiro, Brasil
}

\author{
Genise Vieira Somner ${ }^{1,3}$, André Luiz Gomes de Carvalho ${ }^{1}$ \\ \& Clarice Tavares Siqueira ${ }^{1,2}$
}

\begin{abstract}
Resumo
(Sapindaceae da Restinga da Marambaia, Rio de Janeiro, Brasil) Este trabalho apresenta um estudo florístico de Sapindaceae na Restinga da Marambaia, Rio de Janeiro (entre $23^{\circ} 04^{\prime}$ S, $44^{\circ} 00^{\prime} \mathrm{W}$ e $23^{\circ} 02^{\prime} \mathrm{S}, 44^{\circ} 34^{\prime} \mathrm{W}$ ). Foram identificados 6 gêneros e 14 espécies: uma arbustivo-arbórea Allophylus puberulus (Cambess.) Radlk.; duas arbóreas Cupania emarginata Cambess. e Matayba intermedia Radlk.; uma erva escandente Cardiospermum corindum L. e dez trepadeiras, Paullinia coriacea Casar., Paullinia meliifolia Juss., Paullinia racemosa Wawra, Paullinia revoluta Radlk., Paullinia trigonia Vell., Serjania cuspidata Cambess., Serjania dentata (Vell.) Radlk., Serjania eucardia Radlk., Serjania ichthyoctona Radlk. e Urvillea rufescens Cambess. Dentre os táxons registrados, destacam-se Paullinia coriacea, espécie exclusiva de restingas; Paullinia revoluta, como nova ocorrência para o estado do Rio de Janeiro e Cardiospermum corindum, espécie registrada por um único exemplar coletado há 32 anos e sem novos registros desde então.
\end{abstract}

Palavras-chave: Sapindaceae, florística, restinga.

\section{Abstract}

(Sapindaceae of the Marambaia Restinga, Rio de Janeiro, Southeastern Brazil) This work presents a floristic study of Sapindaceae in the Marambaia Restinga, Rio de Janeiro (between $23^{\circ} 04^{\prime} \mathrm{S}, 44^{\circ} 00^{\prime} \mathrm{W}$ and $23^{\circ} 02^{\prime} \mathrm{S}$, $\left.4^{\circ} 34^{\prime} \mathrm{W}\right)$. We recorded six genera and 14 species: one shrubby-arboreal Allophylus puberulus (Cambess.) Radlk.; two arboreal Cupania emarginata Cambess. and Matayba intermedia Radlk.; one arching herb Cardiospermum corindum L., and ten climbing plants, Paullinia coriacea Casar., Paullinia meliifolia Juss., Paullinia racemosa Wawra, Paullinia revoluta Radlk., Paullinia trigonia Vell., Serjania cuspidata Cambess., Serjania dentata (Vell.) Radlk., Serjania eucardia Radlk., Serjania ichthyoctona Radlk., and Urvillea rufescens Cambess. Among the recorded taxa we highlight Paullinia coriacea, a species exclusive to restingas; Paullinia revoluta, a new record for the State of Rio de Janeiro; and Cardiospermum corindum, recorded through a unique specimen collected 32 years ago, without new records ever since.

Key words: Sapindaceae, floristics, restinga.

\section{INTRODUÇÃO}

Poucas regiões brasileiras foram alvo de investimento amostral capaz de abranger um número significativo de grupos botânicos. Estudos taxonômicos são escassos, havendo, em geral, publicações de listas florísticas desprovidas de detalhamento taxonômico. As Regiões Sul e Sudeste do Brasil podem ser consideradas as mais bem amostradas e investigadas sob esse crivo, possuindo como destaque a publicação das floras de alguns de seus estados, como a Flora Fanerogâmica do Estado de São Paulo, a Flora Ilustrada Catarinense e a Flora Riograndenses (Peixoto $\&$ Thomas 2005). A flora do estado do Rio de
Janeiro encontra-se em fase inicial de elaboração, o que torna inventários e estudos de floras locais fundamentais.

No estado do Rio de Janeiro, áreas de restinga foram intensamente amostradas ao longo das últimas décadas, o que permitiu descrições gerais e comparativas de sua diversidade (Araujo \& Maciel 1998; Araujo 2000). Para estas áreas, verifica-se um volume substancial de trabalhos dedicados a levantamentos florísticos, no entanto, poucos se voltaram ao estudo das famílias botânicas. Destacam-se os de Segadas-Vianna et al. (1965-1978), apresentado em fascículos, onde foram descritas e ilustradas espécies de

Artigo recebido em 01/2009. Aceito para publicação em 06/2009.

${ }^{1}$ Universidade Federal Rural do Rio de Janeiro, Instituto de Biologia, Depto. Botânica, C.P. 74582, BR 465, km 47, 23.851-970, Seropédica, RJ, Brasil.

${ }^{2}$ Bolsista de Iniciação Científica da Fundação de Amparo à Pesquisa do Estado do Rio de Janeiro (FAPERJ).

${ }^{3}$ Autor para correspondência: somner@ufrrj.br 
algumas famílias botânicas das restingas do sudeste do Brasil; Oliveira-Filho et al. (1989), sobre as Euphorbiaceae das restingas do estado do Rio de Janeiro; Pereira et al. (1997), sobre as Asclepiadaceae da Área de Proteção Ambiental de Massambaba; Somner (2001), sobre as Sapindaceae da flora do Parque Nacional da Restinga de Jurubatiba e arredores; Lobão et al. (2005), sobre as Annonaceae das restingas do estado do Rio de Janeiro; Fraga et al. (2005), sobre as Orchidaceae da Marambaia; Reis (2006), sobre as Arecaceae das restingas do estado do Rio de Janeiro; Nunes-Freitas et al. (2006), sobre as Bromeliaceae da restinga da Reserva Biológica Estadual da Praia do Sul, na Ilha Grande; Souza et al. (2007) e Souza \& Morim (2008), respectivamente, sobre as subtribos Myrcine, Eugeniinae e Myrtinae (Myrtaceae) na Restinga da Marambaia.

Dentre as restingas fluminenses, a Restinga da Marambaia destaca-se tanto por sua diversidade, como pelo estado de conservação de suas paisagens (Conde et al. 2005; Góes et al. 2005; Menezes \& Araujo 2005). Apesar disso, só recentemente obteve-se a primeira compilação de sua diversidade florística, publicada no livro História Natural da Marambaia (Menezes et al. 2005). Esforços adicionais de coleta e estudos focais das famílias botânicas da Marambaia têm revelado novas ocorrências e servido de base para correção de equívocos na identificação de algumas espécies. Trabalhos em execução adicionaram espécies até mesmo para famílias tidas como bem estudadas, como Acanthaceae, Bignoniaceae, Convolvulaceae, Malpighiaceae, Rubiaceae, Rutaceae e Sapindaceae. Apresentamos, aqui, o primeiro estudo sobre as Sapindaceae da Restinga da Marambaia, incluindo redescrições detalhadas, uma chave para identificação das espécies, além de notas sobre fenologia e distribuição.

\section{Material e Métodos}

A Restinga da Marambaia, compreendida entre os municípios do Rio de Janeiro, Itaguaí e
Mangaratiba (entre $23^{\circ} 04^{\prime} \mathrm{S}, 44^{\circ} 00^{\prime} \mathrm{W}$ e $23^{\circ} 02^{\prime} \mathrm{S}$, 44⒊'W), ocupa uma área de 4.961,31 ha, estendendo-se por $40 \mathrm{~km}$ de sedimentos marinhos (Roncarati \& Menezes 2005). Enquadra-se no macroclima tipo AW - Clima Tropical Chuvoso (Köppen 1948), cuja temperatura média do mês mais frio é superior a $18^{\circ} \mathrm{C}$ e a do mês mais quente superior a $22^{\circ} \mathrm{C}$ (Mattos 2005). Esta área é constituída por uma faixa estreita, plana e arenosa que reúne um mosaico composto por 11 formações vegetais (Menezes \& Araujo 2005).

O levantamento das espécies de Sapindaceae foi realizado entre agosto/2003 e julho/2006. Os espécimes foram coletados através de caminhadas livres ao longo de trilhas nas diversas formações vegetais. Seguiu-se a herborização conforme métodos convencionais (Mori et al. 1985) e, posteriormente, o material botânico foi incorporado à coleção do Herbário do Departamento de Botânica da Universidade Federal Rural do Rio de Janeiro (RBR).

Os espécimes foram identificados com o auxílio de bibliografia especializada, como Radlkofer(1892-1900; 1931-1934), e as descrições taxonômicas basearam-se principalmente na análise de amostras herborizadas. A terminologia usada nas descrições das espécies seguiu Radford et al. (1974) eWeberling (1989). Material adicional foi acessado nos seguintes herbários: Herbário Alberto Castellanos (GUA), Museu Nacional (R), Instituto de Pesquisas Jardim Botânico do Rio de Janeiro (RB).

A partir dos dados obtidos, elaborou-se uma chave dicotômica das espécies encontradas na Restinga da Marambaia. Os dados fenológicos, distribuição geográfica e nomes vulgares foram complementados através da literatura - Corrêa \& Penna (1952, 1975), Reitz (1980) e Beck (1990), e materiais de herbário. As formações vegetais de ocorrência de cada espécie foram registradas seguindo a classificação proposta por Menezes \& Araujo (2005).

Foram utilizadas nas descrições das espécies e na lista de materiais examinados as seguintes abreviaturas: alt. (altura), flor estam. 
(flor estaminada), flor pist. (flor pistilada), compr. (comprimento), larg. (largura), diâm. (diâmetro), est. (estéril), bt. (botão), fl. (flores), fr. (frutos), s.c. (sem coletor), s.n. (sem número), s.d. (sem data).

\section{Resultados e Discussão}

Das 27 espécies de Sapindaceae citadas na lista florística das restingas do estado do Rio de Janeiro (Araujo 2000), 17 foram citadas por Menezes \& Araujo (2005) para a Restinga da Marambaia. No entanto, após a revisão dos espécimes depositados no herbário RBR (empregados para a confecção da lista florística publicada por esses autores), foram constatadas falhas de identificação. Cupania oblongifolia Mart., Paullinia micrantha Cambess. e Paullinia weinmanniifolia Mart. não ocorrem na Restinga da Marambaia; as duas primeiras, contudo, são registradas em áreas montanhosas cobertas por floresta ombrófila densa submontana na Ilha da Marambaia. Além disso, duas espécies do gênero Matayba Aubl. foram erroneamente listadas para a Marambaia, quando somente Matayba intermedia é conhecida para esta área.

Após este estudo, 14 espécies de Sapindaceae foram reconhecidas para a Restinga da Marambaia. Este valor de riqueza a coloca como a segunda restinga mais rica em espécies desta família em todo o estado do Rio de Janeiro. A restinga de Cabo Frio, com 16 espécies (Araujo 2000), é a única que ultrapassa a Marambaia em número de representantes da família Sapindaceae. Todas as demais restingas do Estado apresentam riqueza igual ou inferior a 11 espécies. A restinga de Jurubatiba, por exemplo, porta 11 espécies (Somner 2001), assim como a de Jacarepaguá (Araujo 2000); Ipitangas reúne dez espécies (Sá 1992), seguida pela Restinga de Grumari, com nove espécies (Araujo 2000); Maricá, com sete espécies (Silva \& Oliveira 1989) e pela Reserva da Praia do Sul, localizada na Ilha Grande, com apenas quatro espécies (Araujo 2000). A tomar pelo exemplo da Marambaia, um incremento no número de espécies de Sapindaceae para algumas das áreas citadas é provável, no futuro. Para isso, além da ampliação dos esforços de coleta, um investimento focal no estudo taxonômico da família mostra-se indispensável.

$\mathrm{Na}$ Marambaia foram registrados quatro hábitos distintos para as espécies de Sapindaceae: uma espécie arbustivo-arbórea, Allophylus puberulus (Cambess.) Radlk.; duas arbóreas, Cupania emarginata Cambess. e Matayba intermedia Radlk.; uma erva escandente Cardiospermum corindum L., e dez trepadeiras, Paullinia coriacea Casar., $P$. meliifolia Juss., $P$. racemosa Wawra, $P$. revoluta Radlk., P. trigonia Vell., Serjania cuspidata Cambess., S. dentata (Vell.) Radlk., S. eucardia Radlk., S. ichthyoctona Radlk. e Urvillea rufescens Cambess. Dentre as espécies listadas, destacam-se $P$. revoluta como uma nova ocorrência para o estado do Rio de Janeiro e $P$. coriacea como espécie exclusiva de restingas. Vale notar também que o registro de Cardiospermum corindum para a Marambaia deu-se a partir de um único exemplar (RB 132535) coletado em 1966. Desde então, essa espécie jamais foi registrada para esta área.

Das 11 formações vegetais encontradas na Restinga da Marambaia, em apenas quatro foram registradas espécies de Sapindaceae (Tab. 1). As áreas cobertas por floresta de cordão arenoso são as mais ricas em representantes desta família, portando dez espécies; seguidas pela formação arbustiva fechada de cordão arenoso, com sete espécies; a floresta inundável, com quatro; e a formação arbustiva aberta não inundável, com apenas duas. O registro de Sapindaceae para as formações herbáceas não era de fato esperado, visto não ser hábito comum na família.

\section{A família Sapindaceae}

Árvores, arbustos, subarbustos eretos ou decumbentes, lianas ou raro trepadeiras herbáceas; monóicas, raro dióicas; latescentes 
Tabela 1 - Distribuição das espécies de Sapindaceae nas formações vegetais da Restinga da Marambaia. AANI: formação arbustiva aberta não inundável; AFCA: formação arbustiva fechada de cordão arenoso; FI: floresta inundável; FCA: floresta de cordão arenoso.

Table 1 - Distribution of the Sapindaceae species in the plant communities of the Marambaia Restinga. AANI: nonflooded scrub; AFCA: dune thicket; FI: seasonally flooded swamp; FCA: ridge forests.

\begin{tabular}{|c|c|c|c|c|}
\hline \multirow[t]{2}{*}{ Espécies } & \multicolumn{4}{|c|}{ Formações } \\
\hline & AANI & AFCA & FI & FCA \\
\hline Allophylus puberulus (Cambess.) Radlk. & & $\mathbf{\square}$ & & $\mathbf{\square}$ \\
\hline Cardiospermum corindum L.* & & & & \\
\hline Cupania emarginata Cambess. & & घ & & - \\
\hline Matayba intermedia Radlk. & घ & & & $\mathbf{\square}$ \\
\hline Paullinia coriacea Casar. & - & घ & घ & $\boldsymbol{\square}$ \\
\hline Paullinia meliifolia Juss. & & & & $\mathbf{\square}$ \\
\hline Paullinia racemosa Wawra & & & घ & $\mathbf{\square}$ \\
\hline Paullinia revoluta Radlk. & & & & - \\
\hline Paullinia trigonia Vell. & & & घ & \\
\hline Serjania cuspidata Cambess. & & घ & & घ \\
\hline Serjania dentata (Vell.) Radlk. & & घ & & $\mathbf{\square}$ \\
\hline Serjania eucardia Radlk. & & घ & & \\
\hline Serjania ichthyoctona Radlk. & & & & घ \\
\hline Urvillea rufescens Cambess. & & a & घ & \\
\hline
\end{tabular}

* Sem informação sobre a formação vegetal de ocorrência. / Without information with respect to the plant communities.

ou não; caule simples (um único cilindro central) ou composto (um cilindro vascular central maior e cilindros vasculares periféricos menores) em algumas espécies de trepadeiras; com ou sem estípulas, pecioladas, raque nua, marginada ou alada. Folhas compostas, paripinadas ou imparipinadas, às vezes pinadas (3-folioladas, 5-folioladas, biternadas ou 3-4jugadas), bipinadas, alternas ou subopostas, margem geralmente denteado-serreada, inteira ou subinteira. Tirso simples ou composto, nas trepadeiras 2 gavinhas na base da raque. Flores diclinas ou raramente monoclinas; actinomorfas ou zigomorfas; cálice tetrâmero com 2 sépalas externas e 2 internas ( 1 anterior e 1 posterior), a anterior emarginada, ou pentâmero com 2 sépalas externas e 3 internas (1 sépala posterior e 2 sépalas anteriores), livres ou concrescidas, cuculadas; corola 4-5-mera, raro ausente, pétalas livres, unguiculadas, alternas às sépalas, geralmente com apêndice basal; nectários florais extra-estaminais, em forma de disco anelar ou fragmentados em 4 lobos (2 posteriores e 2 anteriores), ou somente 2 posteriores, de formas variadas, na base do androginóforo; flores pistiladas com estaminódios e estaminadas com pistilódio, androceu cêntrico ou excêntrico, estames 8 , livres ou soldados na base, anteras bitecas, geralmente dorsifixas, indeiscentes; pólen em mônades, raro tétrades; gineceu cêntrico ou excêntrico, estaminódios 8 , semelhantes aos estames; ovário súpero, (2)3-carpelar, (2)3locular, 1 óvulo anátropo por lóculo, placentação axial, estilete filiforme, estigma bífido, trífido ou com lóbulos soldados. Fruto cápsula loculicida ou septífraga, esquizocárpico com mericarpos samaróides ou cocos drupáceos; sementes exalbuminadas, não aladas, com ou sem arilo; embrião curvo, radícula geralmente alojada em uma dobra do tegumento. 


\section{Chave para identificação das espécies ocorrentes na Restinga da Marambaia}

1. Subarbusto escandente ou trepadeiras com gavinhas.

2. Frutos cápsulas septífragas.

3. Cápsula subcarnosa, avermelhada; sementes com arilo carnoso.

4. Folhas 3-folioladas

5. Paullinia coriacea

4'. Folhas 5-folioladas, biternadas ou 3-4-jugadas, os folíolos basais 3-foliolulados

5. Estípulas foliáceas, cuneiformes, subfalcadas e assimétricas; sépalas 5; cápsula com 1 semente; cotilédones subretos ....... 6. Paullinia meliifolia

5'. Estípulas não foliáceas, ovadas, linear-subuladas, triangulares ou deltóides; sépalas 4; cápsula com 3(1-2) sementes; cotilédone externo curvo e interno biplicado.

6. Folíolos com margem inteira; folíolos basais geralmente com 1 ou 2 pares de foliólulos reduzidos; cápsula com margem da ala revoluta ....

7. Paullinia racemosa

6'. Folíolos com margem subinteira ou serreado-denteada; folíolos basais sem foliólulos reduzidos; cápsula com margem da ala plana.

7. Cápsula obtriangular, 1,5-4×1,3-3,3 cm; estípulas linear-subuladas 8. Paullinia revoluta

7’. Cápsula elipsóide ou obovóide, 1,2-1,5 × 0,5-0,8 cm; estípulas ovadas

9. Paullinia trigonia

3'. Cápsula membranácea, castanho-avermelhada ou castanho-clara; sementes com arilo seco.

8. Folhas biternadas; folíolos cartáceos, com margem denteado-serreada ou incisodenteada; cápsula não alada ou estreitamente alada, totalmente inflada; pericarpo castanho-avermelhado

2. Cardiospermum corindum

8'. Folhas 3-folioladas; folíolos subcoriáceos, denteado-crenados; cápsula alada, alas tão largas quanto 2-4 vezes a largura do lóculo, inflada na porção central dos lóculos; pericarpo castanho-claro

14. Urvillea rufescens

2'. Frutos esquizocárpicos com 3 mericarpos samaróides.

9. Ramos floríferos triangulares, caule composto (um cilindro vascular central maior e três periféricos menores equidistantes).

10. Ramos floríferos com tricomas longos, rígidos e ferrugíneos nos ângulos; porção seminífera dos mericarpos achatada lateralmente; sementes lenticulares; folíolos com ápice cuspidado e face adaxial opaca

10. Serjania cuspidata

10’. Ramos floríferos glabros; porção seminífera dos mericarpos globosa; sementes obovóides; folíolos com ápice aguado a acuminado e face adaxial brilhante .......

13. Serjania ichthyoctona

9'. Ramos floríferos 5-angulosos ou 5-6 costados; caule simples, fistuloso.

11. Trepadeira glabra; folhas 3 -folioladas; folíolos frequentemente conduplicados, $o$ terminal obovado e margem com 1 a 2 pares de dentes no terço superior; crista dos apêndices das pétalas posteriores bicorniculada; mericarpos 2,5-3,2 $\times 1$ $2,7 \mathrm{~cm}$

11. Serjania dentata

11'. Trepadeira velutino-pubescente; folhas biternadas; folíolos não conduplicados, o terminal ovado a romboidal e margem serreado-dentada; crista dos apêndices das pétalas posteriores emarginada; mericarpos 3,2-5 × 1,2-1,8 cm 
1'. Árvore, arvoreta ou arbusto.

12. Folhas 3-folioladas; drupa avermelhada 1. Allophylus puberulus

12'. Folhas paripinadas; cápsula loculicida, amarelada ou castanha.

13. Folíolos com margem plana, nervuras da face adaxial inconspícuas; cálice com prefloração aberta, sépalas dispostas em um único verticilo; ovário 3-locular; cápsula trígono-obovóide ou subglobosa.

4. Matayba intermedia

13'. Folíolos com margem revoluta, nervuras da face adaxial conspícuas; cálice com prefloração fechada, sépalas dispostas em dois verticilos; ovário 2-locular; cápsula obcordiforme

3. Cupania emarginata

1. Allophylus puberulus (Cambess.) Radlk. in Engl. \& Prantl., Nat. Pflanzenfam. 3(5): 312. 1895.

Fig. 1 a-d

Árvore ou arbusto dióico, 1,5-3,5 m; ramos cilíndricos com lenticelas lineares, pubescentes a glabrescentes. Folhas 3folioladas; pecíolo 1,3-5,8 cm; folíolos elípticos, ovados ou obovados, 4,4-9,8 $\times 2-5,5 \mathrm{~cm}$, cartáceos, discolores, base aguda, decorrente, cuneada ou assimétrica, ápice agudo a acuminado, margem crenada, face adaxial glabra e abaxial subglabra ou incanopubescente nas nervuras, com domácias. Tirso simples, axilar ou terminal, pubescente, pedúnculo $0,2-3,2 \mathrm{~cm}$, raque $1-4,2 \mathrm{~cm}$; bractéolas ca. 0,5 mm compr., ovadas, pubescentes, margem ciliada; pedicelos 0,5$1,3 \mathrm{~mm}$. Flores ca. $3 \mathrm{~mm}$, brancas, zigomorfas; sépalas 4 , livres, ovadas, 1,1-2 mm compr.; pétalas 4, obovadas, 1,5-1,9 $\mathrm{mm}$ compr., margem ciliada, glândulas na face adaxial; apêndice da pétala com ápice bilobado, trilobado ou lobado irregularmente e porção deflexa curta, vilosa; disco nectarífero amarelado, 5lobado, glabro; flor estam. com androceu excêntrico, estames brancos, 1,7-2,5 mm compr., pubescentes, até $3 / 4$ do filete; antera com raros tricomas; pistilódio ca. $0,5 \mathrm{~mm}$, piloso; flor pist. com gineceu excêntrico, ca. 2 $\mathrm{mm}$, ovário globoso, 2-carpelar, 2-locular, um óvulo por lóculo, placentação axial; estilete 1$1,2 \mathrm{~mm}$ compr., terminal, estigma bífido, estaminódios ca. 0,8 mm. Drupa avermelhada, globosa, $0,6-0,8$ cm diâm., epicarpo membranáceo, liso, glabro, mesocarpo carnoso, endocarpo lenhoso; semente 1, obovóide, 0,4-0,6×0,4$0,5 \mathrm{~cm}$, testa alaranjada, lisa, quebradiça, tegma castanha e membranácea; embrião 3,5-4,5 mm diâm., globoso, cotilédone externo curvo e interno biplicado.

Nomes populares: fruta-de-café e fruta-desaíra.

Material selecionado: BRASIL. RIO DE JANEIRO: Mangaratiba, Restingas da Marambaia, Ponta do Varejo, 18.X.2005, fl., D. C. Carvalho 66(RBR); Ilha da Marambaia, Praia do Sino, 12.II.2002, fl., L. F. T. Menezes 996 (RBR); Ilha da Marambaia, Praia do Caetano, 7.VII.1993, fl., G. V. Somner \& A. Ururahy 779 (RBR). Rio de Janeiro, Restinga da Marambaia, entrada próxima à Praia da Barra de Guaratiba, no Campo de Provas do Exército, linha 4, na floresta de cordão arenoso, 13.IX.2000, fr., L. F. T. Menezes 461 (RBR); Ibidem, 29.VIII.2004, fl., G. V. Somner et al. 1165 (RBR); Área próxima da Guarita, margem da estrada indo para a linha 4 , na formação arbustiva fechada de cordão arenoso, 31.VII.2004, fl., G V V. Somner et al. 1162 (RBR); Ibidem, 28.I.2005, fr., G. V. Somner et al. 1169 (RBR).

Distribuição e fenologia: Ocorre nos estados de Alagoas, Bahia, Espírito Santo, Goiás, Paraná, Pernambuco, Rio Grande do Norte e Rio de Janeiro. No estado do Rio de Janeiro é encontrada nas restingas e, eventualmente, na floresta ombrófila densa. Na Restinga da Marambaia é abundante, ocorre nas formações arbustiva fechada de cordão arenoso e floresta de cordão arenoso. Coletada com flores em fevereiro e de julho a outubro, com frutos em janeiro e setembro.

2. Cardiospermum corindum L., Sp. pl., ed. 2, 526. 1762 .

Fig. 1 e-i

Erva escandente ou trepadeira herbácea, monóica; ramos floríferos 5-6-costados, caule fistuloso. Folhas biternadas; estípulas 0,5-2,5 mm, triangular-subuladas; pecíolo $0,2-4 \mathrm{~cm}$; folíolos $0,6-6,3 \times 0,5-3,8 \mathrm{~cm}$, ovados, às vezes pinatipartido 

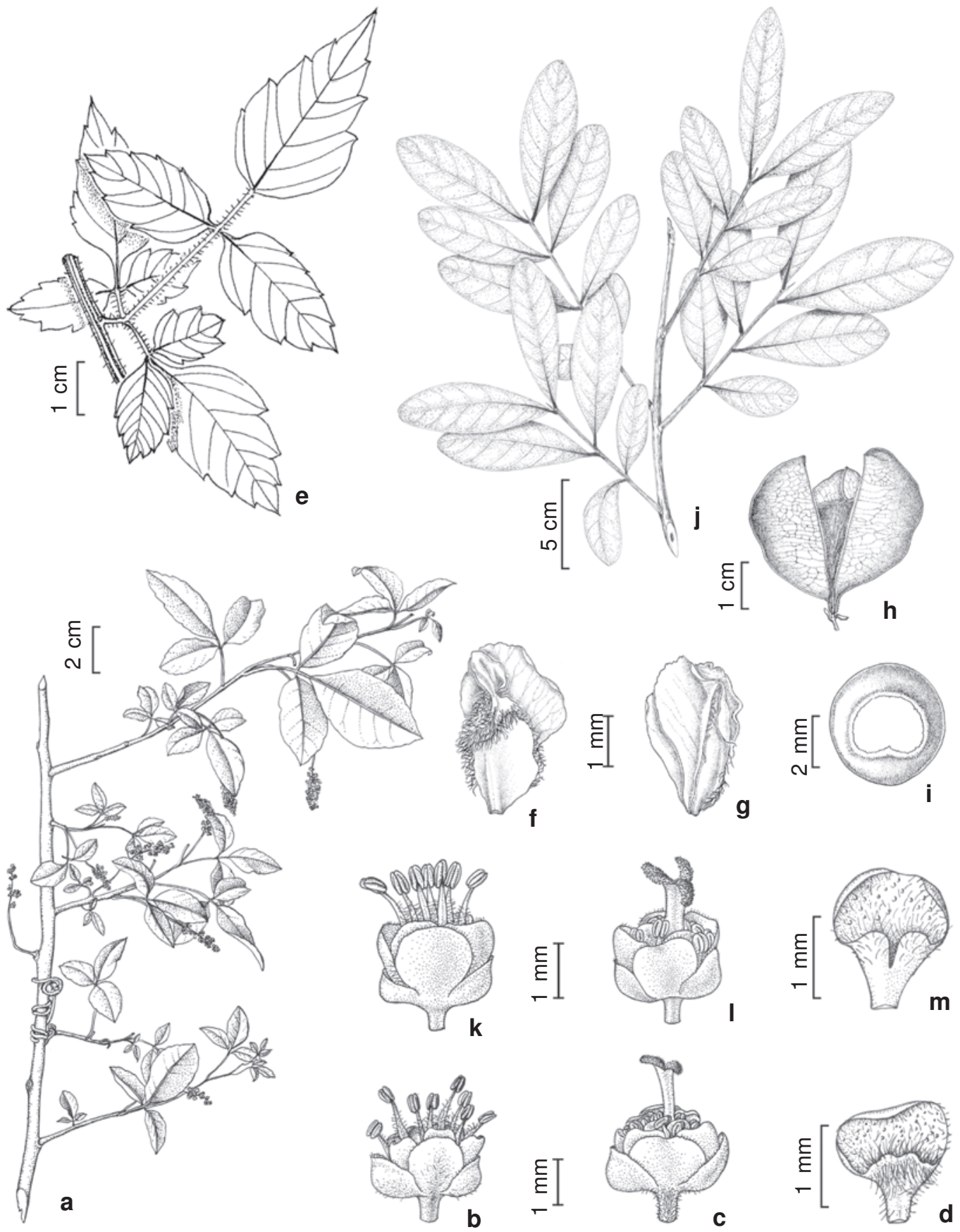

Figura 1 - a-d. Allophylus puberulus (Cambess.) Radlk. - a. ramo florífero; b. flor estaminada; c. flor pistilada; d. pétala com apêndice. e-i. Cardiospermum corindum L. - e. ramo vegetativo; f. pétala posterior com apêndice; g. pétala anterior com apêndice; h. cápsula septífraga; i. semente. j-m. Cupania emarginata Cambess. - j. ramo vegetativo; k. flor estaminada; 1. flor pistilada; m. pétala com apêndice. (a-b D.C. Carvalho 66; c-d G.V. Somner et al. 1162; e G. Hatschbach et al. 77664; f-g D. Sucre 3742; h-i G. Hatschbach et al. 77664; j-m C. Farney et al. 2294).

Figure 1 - a-d. Allophylus puberulus (Cambess.) Radlk. - a. flowering branch; b. staminate flower; c. pistillate flower; d. petal with appendage. e-i. Cardiospermum corindum L. - e. vegetative branch; f. posterior petal with appendage; g. anterior petal with appendage; h. septifragal capsule; i. seed. j-m. Cupania emarginata Cambess. - j. vegetative branch; k. staminate flower; 1. pistilate flower; m. petal with appendage. (a-b D.C. Carvalho 66; c-d G.V. Somner et al. 1162; e G. Hatschbach et al. 77664; f-g D. Sucre 3742; h-i G. Hatschbach et al. 77664; j-m C. Farney et al. 2294). 
ou pinatisecto, cartáceos, base arredondada, decorrente ou cuneada, ápice atenuado a acuminado, margem denteado-serreada ou inciso-denteada, ciliada, face adaxial pubérula ou setosa nas nervuras principais, face abaxial glabra ou pubescente. Tirso geralmente racemiforme, com 1 par de gavinhas na base, pedúnculo $1,1-5,5 \mathrm{~cm}$, raque $0,6-1,4 \mathrm{~cm}$, com 4(3) ou mais cincinos subverticilados; bractéolas triangulares, 1-1,5 mm; pedicelos 1-2,5 mm. Flores 3-6 mm, zigomorfas; sépalas 5, livres, externas 1-2,5 mm, suborbiculares, internas 3,5-5 mm, obovadas ou oblongas; pétalas 4 , brancas, 3,5-6 $\mathrm{mm}$, crista dos apêndices das pétalas posteriores erosa ou emarginada; lobos nectaríferos 4, posteriores ovóides ou suborbiculares, anteriores ausentes; androginóforo glabro; flor estam. com androceu excêntrico, estames 2,5-4,5 mm, pistilódio glabro; flor pist. com gineceu excêntrico, ca. $4 \mathrm{~mm}$, ovário trígono-elipsóide, viloso ou com tricomas glandulares, estaminódios 2,5-3 mm. Cápsula septífraga, inflada, castanha ou castanhoavermelhada, esférica a largo-obovóide, 2,2$5,9 \times 2-4,2 \mathrm{~cm}$, membranácea, não alada ou estreitamente alada, levemente apiculada ou emarginada, estípite 1,5-5 mm, epicarpo piloso ou pubérulo, endocarpo glabro; sementes 3(12), pretas, subesféricas, 3-7 mm diâm., com arilo seco, branco, semicircular ou levemente emarginado; embrião globoso, ca. 0,4 cm diâm., cotilédone externo curvo e interno biplicado.

Material selecionado: BRASIL, RIO DE JANEIRO: Rio de Janeiro, Restinga da Marambaia, km 15 da estrada, 20.X.1966, fl., E. Guimarães 67 (RB).

Material adicional examinado: BRASIL, BAHIA:

Bom Jesus da Lapa, 9.VIII.1996, fl.fr., M. S. Ferrucci et al. 987 (CTES). MINAS GERAIS: Itaobim, 14.VI.1986, fl.fr., G. Hatschbach \& M. Silva 50392 (CTES); Curimataí, orla da floresta de galeria, 9.VI.2004, fl.fr., G. Hatschbach et al. 77664 (CTES). PERNAMBUCO: Ouricuri, 7.VII.1983, fr., G. Costa Lima 93 (CTES). PIAUÍ: Parnaíba, 3.X.1973, fl. fr., D. Araujo et al. 443 (RB). RIO DE JANEIRO: Cabo Frio, Restinga de Palmares, 20.IX.1968, fl., D. Sucre 3742(CTES). ARGENTINA: Formosa, 2.V.1975, fl.fr., A. L. Cabrera et al. 26562 (CTES).

Distribuição e fenologia: Espécie com ampla distribuição, ocorre nas Américas, África e Ásia
(Ferrucci 1991). Nas Américas estende-se dos Estados Unidos até o centro da Argentina. No Brasil ocorre em todos os estados. Um único exemplar foi coletado na Restinga da Marambaia em 1966 (RB 132535), não havendo registro da formação vegetal de ocorrência desta espécie. Coletada com flores em outubro.

3. Cupania emarginata Cambess. in St. Hil. Fl. Bras. Merid. 1: 386. $1828 . \quad$ Fig. 1 j-m

Árvore monóica, 3-12 $\mathrm{m}$; ramos estriados, com lenticelas circulares. Folhas paripinadas, 4-10 folíolos; estípulas ausentes; pecíolo $1,5-4,6 \mathrm{~cm}$; raque $1,2-7,5 \mathrm{~cm}$, prolongando-se sob a forma de apículo; folíolos obovados ou elípticos, 2,8-11 × 1,7-5,8 cm, subcoriáceos, base cuneada, decorrente a levemente assimétrica, ápice retuso a emarginado, margem inteira, revoluta, face adaxial castanho-acinzentada, castanho-clara ou verde-amarelada, abaxial castanha, ambas as faces glabras, nervuras na face adaxial conspícuas. Tirso simples ou composto, axilar ou terminal, amarelo-pubescente, pedúnculo 2,9-5,4 cm, raque $2-13,5 \mathrm{~cm}$; bractéolas $0,5-$ 1,5 mm compr., subuladas, pubescentes, pedicelos ca. 0,5 $\mathrm{mm}$. Flores $2-3 \mathrm{~mm}$, actinomorfas; sépalas 5, livres, 1,4-2,1 mm, ovadas, pubescentes, margem ciliada, dispostas em dois verticilos; pétalas 5, brancoamareladas, obovadas, 1,1-1,6 mm compr., margem ciliada, apêndices bífidos, de tamanho igual ou maior ao das pétalas, vilosos; disco nectarífero anelar, lobado; flor estam. com androceu cêntrico, estames 3-3,8 mm, filetes pubescentes até $3 / 4$ do seu comprimento; pistilódio ovóide, 0,6-0,8 mm compr., pubescente; flor pist. com gineceu cêntrico, 3,9-4 mm compr., pubérulo, ovário 2-carpelar, 2-locular, um óvulo por lóculo, placentação central-axial, estilete 2,3-2,5 mm compr., estigma bilobado, estaminódios 2-2,4 mm. Cápsula loculicida, amarelada, obcordiforme, 1,4-2,5 × 1,8-2,4 cm, achatada lateralmente, coriácea, base atenuada, ápice apiculado, epicarpo levemente rugoso, glabro; endocarpo tomentoso; sementes 2, obovóides, 0,8-1 ×1,2$1,5 \mathrm{~cm}$, testa lisa, castanha ou castanho- 
avermelhada, com arilo branco, carnoso, cobrindo totalmente ou quase totalmente a semente, fimbriado-denteado; embrião subgloboso, 0,5-0,8 cm, cotilédones subretos. Nome popular: Camboatá.

Material selecionado: BRASIL, RIO DE JANEIRO: Restinga da Marambaia, Praia da Armação, em floresta de cordão arenoso, 15.VIII.2003, fl., L. F. T. Menezes 1022 (RBR). Rio de Janeiro: Restinga da Marambaia, entrada próxima a Barra de Guaratiba, no Campo de Provas do Exército, linha 4, na floresta de cordão arenoso, 7.VII.1996, fr., G. V. Somner 818 (RBR); Ibidem, 21.IV.1998, fl., M. C. Souza 8 (RBR); Área em frente à Guarita, na formação arbustiva fechada, 15.X.2002, fr., G. V. Somner \& M. S. Ferrucci 1068 (RBR).

Material adicional examinado: BRASIL, RIO DE JANEIRO: Mangaratiba, Ilha da Marambaia, caminho da Matriz, próximo à praia do Sino, floresta ombrófila densa submontana, 10.II.2000, fl., H. R. P. Lima 321 (RBR); Estrada da Senzala, caminho para a Praia da Armação, 11.VIII.2001, fr., G. M. Siqueira \& A. L. Melo s.n. (RBR 12252). Saquarema, Restinga de Ipitangas, floresta de cordão arenoso, 29.III.1989, fl., C. Farney et al. 2294 (RB, RBR).

Distribuição e fenologia: Ocorre nos estados da Bahia, Espírito Santo, Minas Gerais e Rio de Janeiro. É muito comum se apresentar como arvoreta, mas pode alcançar $12 \mathrm{~m}$ de altura. No estado do Rio de Janeiro ocorre preferencialmente nas restingas. Planta muito frequente na Restinga da Marambaia, estendendo-se da restinga até a área de interseção com a floresta ombrófila densa submontana, em região degradada, bastante ensolarada, constituída de solo argiloso-arenoso, chegando a aproximadamente 200 m.s.m. Na Restinga da Marambaia foi registrada nas formações arbustiva fechada de cordão arenoso e floresta de cordão arenoso. Coletada com flores em abril e agosto, e com frutos de julho a outubro.

4. Matayba intermedia Radlk. in Martius, Fl. Bras. 13 (3): 619. $1900 . \quad$ Fig. 2 a-f

Árvore monóica, 3-20 m. Folhas paripinadas, 6-12 folíolos; pecíolo 2,2-4,8 cm; raque $2,5-21,5 \mathrm{~cm}$, prolongando-se sob a forma de apículo; folíolos obovados, elípticolanceolados, oblongos ou oblongo-lanceolados, 4,5-18,5 ×2,5-6 cm, subcoriáceos a coriáceos, discolores, acinzentados, verde-acinzentados ou castanho-acinzentados, brilhantes na face adaxial, e castanho-escuros e opacos na face abaxial, glabros a pubescentes em ambas as faces, base cuneada, decorrente ou assimétrica, ápice obtuso, agudo ou retuso, margem inteira, revoluta, plana, nervuras principais subimpressas, secundárias retas, inconspícuas na face adaxial, aréolas grandes (1-2 mm). Tirso composto, axilar, pubérulo, pedúnculo $0,6-4,5 \mathrm{~cm}$, raque 0,7-7,4 cm; bractéolas ca. 0,5 cm compr., ovadas, pubérulas; pedicelos 0,8-2 mm. Flores 3-8 mm, actinomorfas; sépalas 5, soldadas até 1/3 da base, ovadas, 0,9-1,9 mm, pouco pilosas, margem ciliada, dispostas em um verticilo, pré-floração aberta; pétalas 5, branco-amareladas, obovadas, 0,9-1,7 mm compr., apêndice da pétala bipartido formando 2 linguetas deflexas, menores, iguais ou maiores que a pétala, margem vilosa; disco anelar, glabro; flor estam. com androceu cêntrico, estames 2,5-3,5 $\mathrm{mm}$, filetes pubescentes, pistilódio ovóide, 1,2-1,5 mm, pubescente; flor pist. com gineceu cêntrico, 3,2-3,6 mm compr., pubescente com tricomas adpressos, ovário ovóide, 3-carpelar, 3-locular, estilete 0,6-1 mm, estigma trífido, ferrugíneo-papiloso, estaminódios 0,75-2,6 mm, pubescentes. Cápsula loculicida, castanha, trígono-obovóide ou subglobosa, 0,6$1,6 \times 0,6-1,2 \mathrm{~cm}$, base atenuada, estípite ca. 1 $\mathrm{mm}$; epicarpo subverrucoso, com tricomas castanho-claros, curtos, curvos, adpressos, endocarpo branco-seríceo-lanoso; sementes 3 (1-2), castanho-avermelhadas, 0,6-1,2 × 0,4$0,8 \mathrm{~cm}$, elipsóides, testa castanha, lisa, lustrosa, arilo carnoso, cobrindo até $2 / 3$ da semente; embrião ca. $6 \times 4 \mathrm{~mm}$, elipsóide ou oblongo, cotilédones subretos.

Nomes populares: Camboatá, camboatá-defolha-miúda, mataíba.

Material selecionado: BRASIL, RIO DE JANEIRO: Mangaratiba, Restingas da Marambaia, Bravo VI, formação arbustiva aberta de cordão arenoso, 9.XI.2003, fr., D. N. Castro 31 (RBR); Praia da Armação, 27.IX.1999, fr., L. F. T. Menezes et al. 515 (RBR); Ibidem, 27.IX.1999, fl., L. F. T. Menezes et al. s.n. (RBR 12253); Ibidem, 27.XII.2002, fr., G. V. Somner et al. 1088 (RBR). Rio de Janeiro: Restinga da Marambaia, entrada próxima à Praia da Barra de Guaratiba, no Campo de Provas do Exército, linha 4, na floresta de cordão arenoso, 27.XII.2003, fr., $G$ 


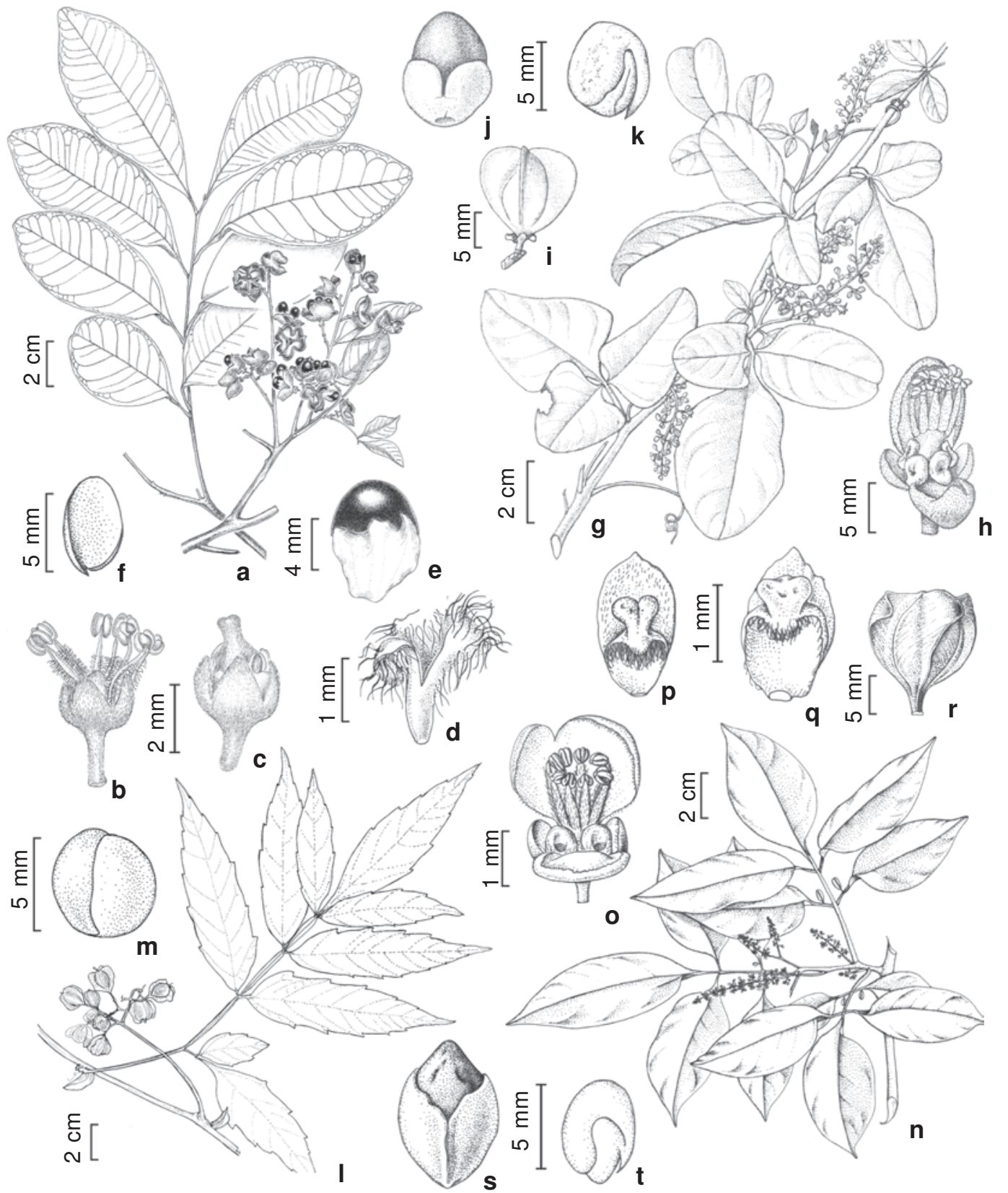

Figura 2 -a-f. Matayba intermedia Radlk. - a. ramo frutífero; b. flor estaminada; c. flor pistilada; d. pétala com apêndice; e. semente arilada; f. embrião. g-k. Paullinia coriacea Casar. - g. ramo florífero; h. flor estaminada; i. cápsula septífraga trialada; j. semente arilada; k. embrião. 1-m. Paullinia meliifolia Juss. - 1. ramo frutífero; m. embrião. n-t. Paullinia racemosa Wawra. - n. ramo florífero; o. flor estaminada; p. pétala posterior com apêndice e crista emarginada; q. pétala posterior com apêndice e crista erosa; r. cápsula septífraga trialada; s. semente arilada; t. embrião. (a L. F. T. Menezes et al. 515; b M. C. Souza 136; c-d G.V. Somner et al. 1022; e-f L. F. T. Menezes et al. 515 ; g-h G. V. Somner \& H. A. de Lima 929; 22-24, i-k G. V. Somner \& A. Arurahy 772; 1-m F. Pinheiro et al. 346; n G. V. Somner 951; o-q G. V. Somner 310; r-t G. V. Somner \& A. Arurahy 772).

Figure 2 - a-f. Matayba intermedia Radlk. - a. fruiting branch; b. staminate flower; c. pistillate flower; d. petal with appendage; e. arillate seed; f. embryo. g-k. Paullinia coriacea Casar. - g. flowering branch; h. staminate flower; i. three-winged septifragal capsule; j. arillate seed; k. embryo. 1-m. Paullinia meliifolia Juss. - 1. fruiting branch; m. embryo. n-t. Paullinia racemosa Wawra. - n. flowering branch; o. staminate flower; p. posterior petal with appendage and emarginate crest; q. posterior petal with appendage and erose crest; r. three-winged septifragal capsule; s. arillate seed; t. embryo. (a L. F. T. Menezes et al. 515; b M. C. Souza 136; c-d G.V. Somner et al. 1022; e-f L. F. T. Menezes et al. 515 ; g-h G. V. Somner \& H. A. de Lima 929; 22-24, i-k G. V. Somner \& A. Arurahy 772; 1-m F. Pinheiro et al. 346; n G. V. Somner 951; o-q G. V. Somner 310; r-t G. V. Somner \& A. Arurahy 772). 
V. Somner et al. 1151 (RBR); Ibidem, 20.X.2000, fl., M. C. Souza 136 (RBR).

Distribuição e fenologia: Ocorre nos estados do Paraná, Rio de Janeiro, Rio Grande do Sul, Santa Catarina e São Paulo. No estado do Rio de Janeiro distribui-se principalmente na floresta de cordão arenoso das restingas, nos outros estados é encontrada na floresta ombrófila densa. Na Restinga da Marambaia ocorre na formação arbustiva aberta não inundável e floresta de cordão arenoso. Coletada com flores de setembro a outubro e com frutos de setembro a dezembro.

\section{Paullinia coriacea Casar., Nov. Stirp.} Bras. Dec. 3: 27.1842. Fig. 2 g-k

Trepadeira lenhosa, latescente, monóica; ramos floríferos subcilíndricos, glabros, com lenticelas elípticas dispostas em fileiras, caule simples. Folhas trifolioladas; estípulas 0,5-1 $\times$ 1-1,5 mm, deltóides, glabras; pecíolo 0,3-5,2 cm; raque nua; folíolos 1,5-9,3×0,7-4,3 cm, ovados, ovado-lanceolados ou elípticos, coriáceos, glabros, base decorrente ou cuneada, ápice agudo, obtuso ou retuso, margem inteira, subrevoluta, domácias na face abaxial. Tirso simples, racemiforme, pubescente, pedúnculo $0,3-2,1 \mathrm{~cm}$, raque $1,2-5,3 \mathrm{~cm}$; cincinos 3-4 floros; bractéolas 0,5-1 mm compr., deltóides, pubérulas; pedicelos 1,5-2 mm. Flores perfumadas, 3-5 mm; sépalas 4, pubescentes, cuculadas, com margem ciliada, externas $0,7-$ 1,2 mm, estreito-ovadas, internas 2-2,2 mm, largo-ovadas; pétalas 4 , brancas, obovadooblongas, 1,7-3 mm, crista dos apêndices das pétalas posteriores emarginada; lobos nectaríferos posteriores suborbiculares, anteriores menores; androginóforo glabro; flor estam. com androceu excêntrico, estames 1,52,7 mm; filetes pubescentes; pistilódio ca. 0,5 mm compr., quase glabro; flor pist. com gineceu 1,9-2,1 mm compr., excêntrico, ovário trígonoovóide, pubérulo nos ângulos, 3-carpelar, 3locular, 1 óvulo por lóculo, estilete $0,5-0,75 \mathrm{~mm}$, estigma trífido, estaminódios 1,5-2,1 mm. Cápsula 3-alada, obovóide, 1,3-1,8 × 1-1,7 cm, estípite ca. $0,5 \mathrm{~mm}$, base decorrente ou séssil, ápice retuso a emarginado, epicarpo estriado obliquamente, glabro, endocarpo tomentoso na margem das valvas; sementes 3 (1-2), obovóides, $0,7-0,9 \times 0,6-0,7 \mathrm{~cm}$, testa lisa, castanho-avermelhada, arilo fendido formando dois lobos, cobrindo até a metade da semente; embrião ca. 3 mm diâm., subgloboso, cotilédone externo curvo e o interno biplicado.

Material selecionado: BRASIL, RIO DE JANEIRO: Mangaratiba, Restingas da Marambaia, Praia da Armação, 15.VIII.2003, fl., L. F. T. Menezes et al. 1024 (RBR); Ilha da Marambaia, Bravo VI, formação arbustiva aberta, 27.XII.2002, fl., G. V. Somner et al. 1092 (RBR); Cerca de $500 \mathrm{~m}$ da Lagoa Vermelha, 6.VII.1993, fr., G. V. Somner \& A. Ururahy 772 (RBR); Bravo VI, área alagada, 23.XII.2005, fl., L. F. T. Menezes 1429 (RBR). Rio de Janeiro: Restinga da Marambaia, entrada próxima à Praia da Barra de Guaratiba, no Campo de Provas do Exército, trilha em frente à Guarita, área em frente à Estação Meteorológica desativada, na formação arbustiva fechada de cordão arenoso, 27.XII.2003, fl., G. V. Somner et al. 1148 (RBR); Linha 2, margem da estrada ao lado do posto velho da Marinha, 26.VII.2003, fr., G V. Somner et al. 1104 (RBR); Linha 4, na floresta de cordão arenoso, 26.III.2004, fr., $G$ V. Somner et al. 1158 (RBR).

Material adicional examinado: BRASIL, RIO DE JANEIRO: Maricá, Restinga de Itaipuaçu, rua 36, próximo à transversal da rua 84 , no segundo cordão arenoso 19.VI.1998, fr, G. V. Somner \& H. A. Lima 929 (RBR).

Distribuição e fenologia: Ocorre nos estados da Bahia, Espírito Santo, Rio de Janeiro e São Paulo. É uma planta exclusiva das restingas. Na Restinga da Marambaia foi encontrada nas formações arbustiva fechada de cordão arenoso, arbustiva aberta não inundável (em moitas, como arbusto, ou como trepadeira), floresta inundável e floresta de cordão arenoso. Coletada com flores de julho a agosto e em dezembro, e com frutos em março e julho.

6. Paullinia meliifolia Juss., Ann. Mus. Natl. Hist. Nat. 4: 347. 1804. Fig. 2 1-m

Trepadeira lenhosa, monóica; ramos floríferos 5-6 costados, glabrescentes, caule simples. Folhas 3(-4)-jugadas, folíolos basais 3-foliolulados; estípulas 0,8-2,7 cm; foliáceas, cuneiformes, subfalcadas e assimétricas, margem ciliada; pecíolo 1,5-4,7 cm, canaliculado, 
com tricomas esparsos; raque alada; folíolos elípticos ou estreito-oblongos, às vezes os terminais ovado-romboidais, 3,4-10,5 × 0,94,2 cm, cartáceos, base aguda, decorrente, arredondada ou assimétrica, ápice acuminado, margem com 2-4 pares de dentes e subrevoluta, face adaxial pubescente apenas na nervura principal, face abaxial pubescente, com tricomas curvos. Tirso simples, racemiforme, esparsopubescente, pedúnculo 4,5-11,5 cm, raque 1,6$12 \mathrm{~cm}$; bractéolas 1-2 mm compr., filiformes; pedicelos 3-5 mm. Flores 3-4 mm; sépalas 5, membranáceas, externas 1-2 mm, ovadas, internas 3-4 mm, obovados, margem ciliada; pétalas 2-4 mm compr., brancas, obovadas; crista dos apêndices das pétalas posteriores emarginada; lobos nectaríferos posteriores ovóides e anteriores orbiculares, menores; androginóforo pubérulo; flor estam. com androceu excêntrico, estames 1,7-3 $\mathrm{mm}$, filetes pubescentes na base; pistilódio trígono-ovóide, ca. $0,7 \mathrm{~mm}$ compr., setoso; flor pist. com gineceu de 2-3 mm compr., excêntrico, ovário 3-carpelar, 3-locular, trígono-ovóide, pubescente nos ângulos, estilete ca. 1,5 mm, estigma trífido, estaminódios 1,5-2 mm compr. Cápsula 3-alada, obovóide, 1,22,1 $\times 1,1-1,3 \mathrm{~cm}$, ápice retuso, base atenuada, estípite 1-4,5 mm; epicarpo estriado obliquamente, glabro, endocarpo lanoso; semente 1, trígonoobovóide, $0,7-0,9 \times 0,6-0,7 \mathrm{~cm}$, testa rugosa, castanho-escura, arilo fendido dorsalmente, cobrindo até a metade da semente; embrião 4,57 mm diâm., subgloboso, cotilédones subretos.

Nomes populares: Timbó-peba, cipó-dequina, cipó-timbó, timbó, timbó-de-folha-grande, timbó-vermelho, timbó-de-cipó e tinguí.

Material selecionado: BRASIL, RIO DE JANEIRO: Mangaratiba, Restinga da Marambaia, Praia do Caju, 16.II.2001, fr., L. F. T. Menezes \& M. C. Souza 792 (RBR).

Material adicional examinado: BRASIL, RIO DE JANEIRO: Angra dos Reis, Ilha Grande, Vila Dois Rios, trilha para a Parnaioca, 21.III.2000, F. Pinheiro et al. 346 (RBR). Cabo Frio, 26.X.1968, fl., D. Sucre 3964 (RBR). Mangaratiba: Ilha da Marambaia, caminho da Matriz, próximo à Praia do Sino, floresta ombrófila densa submontana, 10.II.2000, fr., H. R. P. Lima 337 (RBR); Ilha da Marambaia, trilha da Gruta da Santa, floresta ombrófila densa submontana,
22.XII.1998, fr., L. F. T. Menezes \& C. Souza s.n. (RBR 12045); Ilha da Marambaia, margem da estrada que vai para a Praia da Armação, próximo à Senzala, 31.VII.1997, fr., G V. Somner \& M. S. Ferrucci 824 (RBR). Piraí, Estação Ecológica de Piraí, 1.XII.1983, fl., M. Rosa et al. 150 (RBR).

Distribuição e fenologia: Espécie com distribuição no Paraguai oriental, nordeste da Argentina e Brasil, onde ocorre nos estados da Bahia, Minas Gerais, Mato Grosso do Sul, Paraná, Rio de Janeiro, São Paulo, Santa Catarina e Rio Grande do Sul. Na Marambaia foi encontrada na floresta de cordão arenoso e na floresta ombrófila densa submontana. Coletada com frutos em fevereiro. Paullinia meliifolia é considerada uma planta melífera (Conde et al. 1995), seus frutos servem de alimento para pássaros e quatis.

7. Paulinia racemosa Wawra, Oesterr. Bot. Z. 29: 215. 1879.

Fig. 2 n-t

Trepadeira lenhosa, latescente, monóica; ramos floríferos estriados, lenticelados, glabros, caule simples. Folhas 5-folioladas, geralmente com 1 ou 2 pares de folíolos basais extras, reduzidos, 0,5-8 $\mathrm{mm}$; estípulas 0,5-1,5 mm, triangulares, ápice acuminado, glabras; pecíolo 0,5-6,2 cm, pubérulo; raque nua ou marginada; folíolos elíptico-lanceolados, ovados, ovadolanceolados, oblongos a oblongo-lanceolados, 2,5-9,8 × 1-3,4 cm, glabros, domácias na face abaxial, base decorrente, aguda ou obtusa, ápice agudo a acuminado, margem inteira e subrevoluta. Tirso simples, racemiforme, pubescente, pedúnculo $0,6-6 \mathrm{~cm}$, raque $1,5-$ 13,5 cm; bractéolas 0,5-1 mm compr., deltóides, pubérulas, com tricomas brancos; pedicelos 1$2 \mathrm{~mm}$. Flores 3-5 mm; sépalas 4, margem ciliada, externas 0,7-1 mm compr., ovadas, internas, 2$3 \mathrm{~mm}$ compr., obovadas; pétalas 2-2,7 mm compr., branco-amareladas, obovado-oblongas; crista dos apêndices das pétalas posteriores erosa ou emarginada; lobos nectaríferos posteriores suborbiculares e anteriores menores; androginóforo piloso; flor estam. com androceu excêntrico, estames 1,5-2,5 $\mathrm{mm}$, filetes pubescentes, pistilódio trígono-elipsóide, ca. 0,5 mm compr., com tricomas setosos nos ângulos; flor pist. com gineceu 2,2-2,5 mm compr., 
ovário excêntrico, trígono-elipsóide, pubérulo, 3-carpelar, 3-locular, 1 óvulo por lóculo, estilete ca. 1,5 mm, estigma trífido, estaminódios 1,52 mm. Cápsula 3-alada, obovóide, 1,3-3×1,4$2,6 \mathrm{~cm}$, estípite $2-5 \mathrm{~mm}$, atenuada na base, ápice truncado, alas revolutas; epicarpo estriado obliquamente, glabro, margem das valvas com endocarpo tomentoso; sementes 3 (1-2), trígono-obovóides, 0,7-1×0,5-0,8 cm, castanhas; arilo fendido formando 2 lobos, cobrindo 1/3-2/3 da semente; embrião 4-5 mm diâm., subgloboso, cotilédone externo curvo e o interno biplicado.

Material selecionado: BRASIL, RIO DE JANEIRO: Mangaratiba, Restingas da Marambaia: Floresta inundável, quase chegando à Praia da Gaeta, 26.VI.2004, fr., A. Carvalho 1 (RBR); Praia Grande, 14.V.2002, fr., G. V. Somner et al. 1016 (RBR); Praia da Armação, 29.V.1999, fr., L. F. T. Menezes et al. 582 (RBR).

Material adicional examinado: BRASIL, RIO DE JANEIRO: Barra de São João, entre Unamar e Barra de São João, estrada que vai para São Pedro da Aldeia, 21.XII.1982, fl., G. V. Somner 310 (RBR). Mangaratiba, Ilha da Marambaia, margem direita da estrada que vai para Praia da Armação, antes da entrada da Gruta da Santa, 14.V.1993, G. V. Somner \& A. Ururahy 762; Ibidem, 3.II.1999, fr., G. V. Somner 951 (RBR). Santa Maria Madalena, subida para a Pedra do Desengano, 2.III.2004, fl. fr., R. C. Forzza et al. 2847 (RB).

Distribuição e fenologia: Ocorre nos estados de Alagoas, Bahia, Ceará, Espírito Santo, Maranhão, Minas Gerais, Pará, Pernambuco, Rio de Janeiro, São Paulo e Sergipe. Planta encontrada nas restingas, na floresta ombrófila densa e no carrasco. Na Marambaia foi registrada na floresta de cordão arenoso e na floresta inundável, mas pode também se estender até a margem da floresta ombrófila densa submontana, em região degradada, bastante ensolarada, constituída de solo argiloso-arenoso, chegando a aproximadamente $200 \mathrm{~ms}$. m. Coletada com frutos de maio a junho.

\section{Paullinia revoluta Radlk. Monogr.} Paullinia: 251. 1895.

Fig. 3 a-g

Trepadeira lenhosa ou arbusto escandente, latescente, monóica; ramos floríferos 5-6-costados, lenticelados, glabrescentes, caule simples. Folhas 5folioladas ou biternadas; estípulas 1-3,5 mm, linear-subuladas, pubescentes; pecíolo 3,8-4,6 $\mathrm{cm}$; raque bicanaliculada ou marginada. Folíolos largo-ovados, ovado-lanceolados, largo-elípticos, oblongo-lanceolados, 2,8-12,5 $\times 1,8-6,8 \mathrm{~cm}$, subcoriáceos, glabros, domácias na face abaxial, base aguda, cuneada ou decorrente, ápice agudo ou acuminado, margem inteira, às vezes com 1 ou 2 dentes agudos, ciliada e revoluta. Tirso simples, racemiforme, pubescente, pedúnculo 4,7-10,3 $\mathrm{cm}$, raque 5,2-7,2 cm; bractéolas ca. $3 \mathrm{~mm}$, lanceoladas, pubescentes; pedicelos 0,5-1,5 $\mathrm{mm}$. Flores 3-6 mm; sépalas 4, externas 22,5 $\mathrm{mm}$ e internas 2,7-3,5 mm, ovadas a oblongas, tomentosas; pétalas 2,5-3 $\mathrm{mm}$, branco-amareladas, oblongas a obovadas; crista dos apêndices das pétalas posteriores erosa ou bífida; lobos nectaríferos posteriores ovóides ou orbiculares, pubescentes, os anteriores menores; androginóforo pubescente; flor estam. com androceu excêntrico, estames 1,5-2,5 mm, filetes pubescentes, pistilódio ovóide, ca. $1 \mathrm{~mm}$ compr., pubescente; flor pist. com gineceu de 3-4 mm compr., excêntrico, ovário trigono-ovóide, pubescente nos ângulos, 3-carpelar, 3-locular, 1 óvulo por lóculo, estilete 0,5-0,7 mm, estigma trífido, estaminódios 1,54,5 mm. Cápsula 3-alada, alaranjada ou avermelhada, obtriangular, 1,5-4 ×1,3-3,3 cm, estípite 1-3 mm, base atenuada, ápice retuso a emarginado, alas 0,5-0,6 cm; epicarpo estriado obliquamente, com raros tricomas simples, curvos e tricomas glandulares, margem das valvas com endocarpo tomentoso; sementes 3 (1-2), trígono-obovóides, 0,5-0,7 $\times 0,3-0,5 \mathrm{~cm}$, testa castanha e rugosa, arilo fendido formando 2 lobos, cobrindo $1 / 2-2 / 3$ da semente; embrião ca. 5 mm diâm., subgloboso, cotilédone externo curvo e o interno biplicado. Material selecionado: BRASIL, RIO DE JANEIRO: Mangaratiba, Restinga da Marambaia, Praia da Armação, floresta de cordão arenoso, 13.VII.1998, fr., L. F. T. Menezes \& M. C. Souza 188 (RBR).

Material adicional examinado: BRASIL, ALAGOAS: Divisa Ibateguara e São José da Laje, 

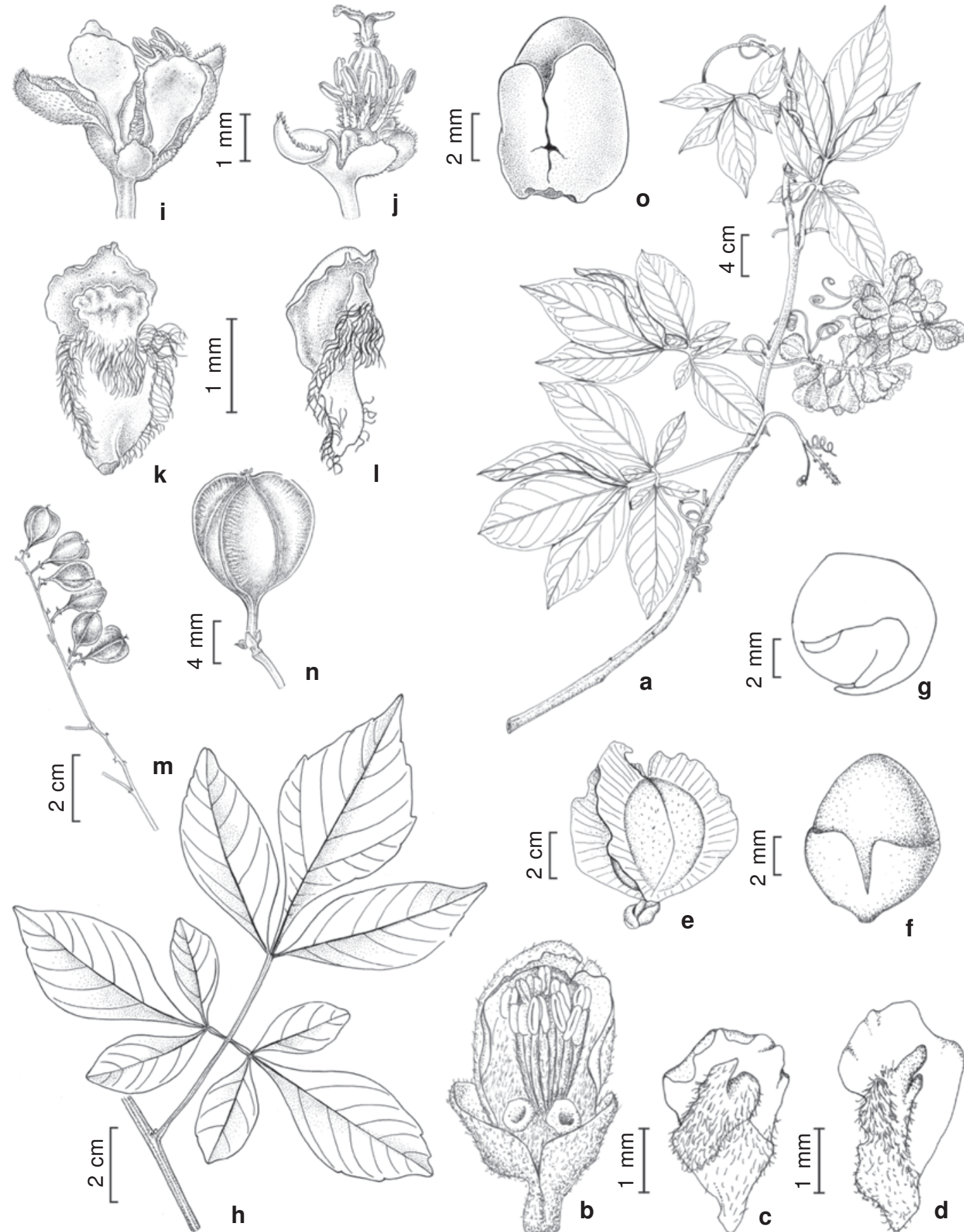

Figura 3 -a-g. Paullinia revoluta Radlk. - a. ramo frutífero; b. flor estaminada; c. pétala posterior com apêndice; d. pétala anterior com apêndice; e. cápsula septífraga trialada; f. semente arilada; g. embrião. h-o. Paullinia trigonia Vell. - h. folha biternada; i. flor estaminada; j. flor pistilada aberta; $\mathrm{k}$. pétala posterior com apêndice; 1 . pétala anterior com apêndice; $\mathrm{m}$. ramo frutífero; n. cápsula septífraga trialada; o. semente arilada. (a O. J. Pereira 513; b-d G. L. Farias 378; e-g O. J. Pereira 513; h-i S. V. A. Pessoa et al. 638; j-1 s.c. 5521; m-o L. F. T. Menezes et al. 1155).

Figure 3 - a-g. Paullinia revoluta Radlk. - a. fruiting branch; b. staminate flower; c. posterior petal with appendage; d. anterior petal with appendage; e. three-winged septifragal capsule; f. arillate seed; g. embryo. h-o. Paullinia trigonia Vell. - h. biternate leaf; i. staminate flower; j. open pistillate flower; $\mathrm{k}$. posterior petal with appendage; 1 . anterior petal with appendage; $\mathrm{m}$. fruiting branch; n. three-winged septifragal capsule; o. arillate seed. (a O. J. Pereira 513; b-d G. L. Farias 378; e-g O. J. Pereira 513; h-i S. V. A. Pessoa et al. 638; j-1 s.c. 5521; m-o L. F. T. Menezes et al. 1155). 
BR 03, 23.IV.2003, fl., M. Oliveira \& A. A. Grillo 1359 (RBR). Marechal Deodoro, Complexo Estuário Lagunar Mundaú-Manguaba, Galhofa, 6.VIII.1998, fr., M. N. Rodrigues et al. 1308 (RBR). ESPÍRITO SANTO: Entre Grumari e Anchieta, 10.XII.1964, fl.fr., Z. A. Trinta \& E. Fromm 2157 (R). Linhares, Reserva Florestal Companhia Vale do Rio Doce, 18.IX.1990, fr., G. L. Farias 378 (RB); Ibidem, campo nativo de mata secundária, 40 ms. m., 12.I.1977, fl., G. Martinelli et al. 1916 (GUA, RB).

Distribuição e fenologia: Ocorre nos estados de Alagoas, Bahia, Espírito Santo, Paraná e Rio de Janeiro. É típica da vegetação de restinga, mas também é encontrada na floresta ombrófila densa, campo nativo e na caatinga. O registro desta espécie na Restinga da Marambaia ampliou sua distribuição geográfica, até então desconhecida para o estado do Rio de Janeiro. Foi encontrada na floresta de cordão arenoso. Coletada com flores em julho.

9. Paullinia trigonia Vell. Fl. Flum. 1: 159. 1829 (1825); tab 30. 1831.

Fig. 3 h-o

Trepadeira lenhosa ou arbusto escandente, latescente, monóica; ramos floríferos estriados, castanho-avermelhados, pubescentes, caule simples. Folhas geralmente biternadas ou 3-4-jugadas, folíolos basais 3foliolulados; estípulas ca. $1 \mathrm{~mm}$, ovadas; pecíolo $1-3,7 \mathrm{~cm}$, canaliculado, ciliado nas margens; raques marginadas ou aladas; folíolos ovados, subromboidais, elíptico-lanceolados ou obovados, 3-6,7 × 1,2-3,3 cm, subcoriáceos, discolores, pubescentes nas nervuras em ambas as faces ou nas nervuras da face adaxial e em toda a face abaxial, domácias nesta última, base decorrente, cuneada ou aguda, ápice agudo, mucronado, margem subinteira a levemente denteado-serreada, subrevoluta, ciliada. Tirso simples, racemiforme, pedúnculo $1,2-6 \mathrm{~cm}$, raque $1,8-4,4 \mathrm{~cm}$, pubescente a tomentosa; bractéolas $0,5-1 \mathrm{~mm}$, deltóides; pedicelos 1,5-1,75 mm. Flores ca. $3 \mathrm{~mm}$; sépalas 4 , externas $1-1,2 \mathrm{~mm}$, ovadas, internas 2-3 mm, obovadas, pubescentes na face adaxial, tricomas glandulares na face abaxial das sépalas internas; pétalas 2-2,5 mm, brancoamareladas, obovados; crista dos apêndices das pétalas posteriores emarginada; lobos nectaríferos posteriores suborbiculares, anteriores menores; androginóforo glabro; flor estam. com androceu excêntrico, estames 1,2$2,7 \mathrm{~mm}$, filetes pubescentes; pistilódio ca. 0,50,7 mm compr., trígono-elipsóide; flor pist. com gineceu excêntrico, 1,5-2 mm compr., ovário trígono-ovóide, 3-carpelar, 3-locular, 1 óvulo por lóculo, estilete ca. $0,2 \mathrm{~mm}$, pubescente, estigma trífido, estaminódios 1,2-1,5 mm. Cápsula 3costada ou 3-alada, trígono-elipsóide ou trígono-obovóide, $1,2-1,5 \times 0,5-0,8 \mathrm{~cm}$, base aguda, ápice agudo a obtuso, estípite $0,5-3 \mathrm{~mm}$; epicarpo estriado obliquamente, subverrucoso, glabro, endocarpo tomentoso nas margens das valvas; sementes $3(1-2)$, tricarenadoelípsóides ou trígono-obovóides, $0,7-0,8 \times 0,5-$ $0,6 \mathrm{~cm}$, testa lisa, castanho-avermelhada, arilo cobrindo até $2 / 3$ da semente, fendida formando 2 lobos; embrião 4-5,5 mm diâm., subgloboso, cotilédone externo curvo e o interno biplicado. Nomes populares: Cipó-timbó, timbó-de-cipó, timbó-aitica, timbó, tinguí-cipó.

Material selecionado: BRASIL, RIO DE JANEIRO: Mangaratiba, Restinga da Marambaia, floresta inundável, quase chegando à Praia da Gaeta, 26.VI.2004, fr., A. L. G. Carvalho et al. 1 (RBR); Ibidem, 11.VI.2004, fr., L. F. T. Menezes et al. 1155 (RBR); Ibidem, 29.VII.2006, fr., G. V. Somner et al. 1150 (RBR).

Material adicional examinado: BRASIL, MINAS GERAIS: Novo Cruzeiro, estrada Palmeiras, para a fazenda Araras, $17^{\circ} 38^{\prime} 42^{\prime \prime}$ S, $41^{\circ} 59^{\prime} 37,7^{\prime \prime} \mathrm{W}$, alt. 810 m, 2.XII.2004, fl., J. R. Stehmann et al. 3681 (BHCB, RBR). RIO DE JANEIRO: Rio de Janeiro, Serra da Estrela, I.1881, fl., s.c. 5521 (R). Silva Jardim, Reserva Biológica de Poço das Antas, estrada para Juturnaíba, entre o portão da REBIO e a trilha para o Morro do Calcário, $22^{\circ} 30 / 22^{\circ} 33 \mathrm{~S}, 42^{\circ} 15 / 42^{\circ} 19$ W, 12.I.1993, fl., S. V. A. Pessoa et al. 638 (RB). SÃO PAULO: Guarujá, 15.III.1951, fl., B. Pickel s.n. (RBR 26588).

Distribuição e fenologia: Ocorre nos estados de Alagoas, Bahia, Espírito Santo, Minas Gerais, Pará, Paraná, Pernambuco, Rio Grande do Sul, Rio de Janeiro, Santa Catarina e São Paulo. Na Restinga da Marambaia foi registrada apenas na floresta inundável. Coletada com frutos de junho a julho. 
Paullinia trigonia é muito semelhante à Paullinia micrantha Cambess. pela forma dos folíolos, raque, flores e frutos, mas difere desta principalmente por apresentar ramos floríferos castanho-avermelhados e folhas geralmente biternadas. Paullinia trigonia é considerada planta venenosa usada para tingüijar peixes (Reitz 1980).

10. Serjania cuspidata Cambess. in St. Hil., Juss. \& Cambess. Fl.. Bras. Mer. 1:275. 1827.

Fig. 4 a-f

Trepadeira monóica; ramos floríferos triangulares, hirsuto-ferrugíneos nos ângulos, caule fistuloso, composto, formado por um eixo lenhoso central maior e três periféricos menores equidistantes. Folhas 3-folioladas; estípulas 3-7 mm, lineares, hirsutas; pecíolo 1,8-6 cm, pubescente; raque nua; folíolos ovados ou ovado-deltóides, trilobados ou 5lobados, 0,2-9,1 × 2,3-7,7 cm, cartáceos, ambas as faces pubescentes, base cuneada ou arredondada, ápice acuminado a cuspidadomucronado, margem ciliada. Tirso simples, racemiforme, 4,7-24,7 cm compr., pedúnculo 2,6-18,4 cm, pubescente, com tricomas hirsutos nos ângulos, raque 2,1-18,2 cm, pubescente; bractéolas 0,5-3 mm compr., lanceoladas, pubescentes e hirsutas; pedicelos 1-2 mm. Flores 1-1,3 cm; sépalas 4, externas 3-3,5 mm e internas ca. $4 \mathrm{~mm}$, a anterior emarginada, margem ciliada, pubérulas; pétalas 6-7,5 mm compr., branco-amareladas, obovadas, longamente unguiculadas, pubescentes, crista dos apêndices das pétalas posteriores erosa ou emarginada; lobos nectaríferos 4, posteriores ovóides e anteriores menores; androginóforo glabro; flor estam. com androceu excêntrico, estames 8, 3-5,5 $\mathrm{mm}$, pubescentes; anteras pouco pilosas; pistilódio trígono-obovóide, 1-1,5 mm compr., piloso nos ângulos; flor pist. com gineceu ca. $5 \mathrm{~mm}$ compr., excêntrico; ovário trígonoobovóide, 3-carpelar, 3-locular, 1 óvulo por lóculo, pubescente, tricomas brancos, estilete 0,75-1 mm compr., estigma trífido, estaminódios 3-4 mm compr., pubescentes. Mericarpos samaróides 3, castanhos, ovado-oblongos ou oblongos, 2,7-3,7 × 1,6-2,6 cm, cartáceos, pubescentes, lóculos no ápice, ao nível dos lóculos 1,4-2,2 cm larg., porção seminífera do mericarpo achatado lateralmente, alas descendentes, crista dorsal 1-2 mm larg., epicarpo pubescente, endocarpo incano-lanoso; sementes 3 , lenticulares, achatadas lateralmente, 0,4-0,7 $\times 0,4-0,5 \mathrm{~mm}$, inseridas na base do lóculo; embrião 5-6 mm diâm., cotilédones subretos. Nomes populares: Cipó-cabeludo, cipód'água, cipó-timbó, guarumina, timbó-de-peixe. Material selecionado: BRASIL, RIODE JANEIRO: Mangaratiba, Restinga da Marambaia, Praia da Armação, 27.XII.2002, fr., G.V. Somner et al. 1091 (RBR).

Material adicional examinado: BRASIL, RIO DE JANEIRO: Mangaratiba, Ilha da Marambaia, trilha da Gruta da Santa, floresta ombrófila densa submontana, 22.XII.1998, fr., L. F. T. Menezes \& M. C. Souza s.n. (RBR 12244); Margem direita da estrada que vai para a Praia da Armação 31.VII.1997, fl.fr., G. V. Somner \& M. S. Ferrucci 834 (RBR). Niterói, restinga da Ilha da Boa Viagem, 18.VII.1990, fl. fr., S. C. Rego 1007 (RBR). Nova Iguaçu, Reserva Biológica do Tinguá, 27.XI.1992, fl.fr., G. V. Somner \& M. Nadruz 737 (RBR). Parati, Parati-Mirim, 18.XI.1992, fl., G. V. Somner et al. 723 (RBR). Saquarema, Reserva Ecológica de Jacarepiá, restinga de Ipitangas, floresta de cordão arenoso, 28.IX.1990, fl., G. V. Somner et al. 611 (RBR).

Distribuição e fenologia: Ocorre nos estados de Alagoas, Bahia, Minas Gerais, São Paulo, Rio de Janeiro e Paraná. Na Restinga da Marambaia ocorre na formação arbustiva fechada de cordão arenoso e na floresta de cordão arenoso, podendo também ser encontrada na floresta ombrófila densa submontana. Coletada com frutos em dezembro.

11. Serjania dentata (Vell.) Radlk., Monogr. Serjania: 144. $1875 . \quad$ Fig. 4 g-k

Trepadeira lenhosa, glabra, monóica; ramos floríferos 5-anguloso, pardacentos, caule simples, fistuloso. Folhas 3-folioladas; estípulas 0,5-1 mm, deltóides, glabras; pecíolo 1,4-5 cm; raque nua; folíolos ovados, ovado-lanceolados, elípticos ou obovados, 3-9,6 × 1,6-4,9 cm, cartáceos, discolores, frequentemente conduplicados, glabros, base decorrente ou 


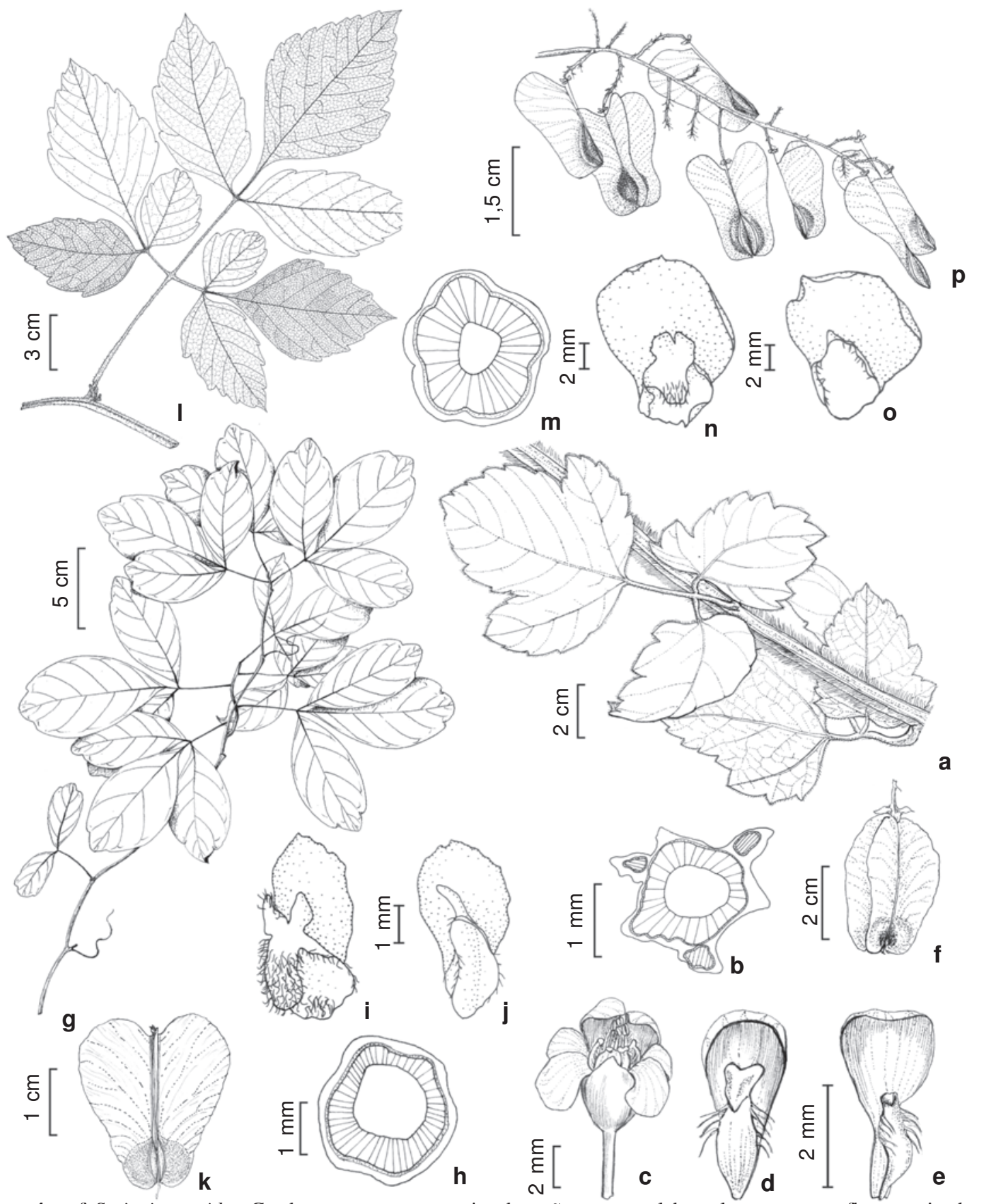

Figura 4- a-f. Serjania cuspidata Cambess. - a. ramo vegetativo; b. seção transversal do caule composto; c. flor estaminada; d. pétala posterior com apêndice; e. pétala anterior com apêndice; f. mericarpos samaróides. g-k. Serjania dentata (Vell.) Radlk. - g. ramo vegetativo; h. seção transversal do caule simples; i. pétala posterior com apêndice; j. pétala anterior com apêndice; k. mericarpos samaróides. 1-p. Serjania eucardia Radlk. - 1. folha biternada; m. seção transversal do caule simples; n. pétala posterior com apêndice; o. pétala anterior com apêndice; p. ramo frutífero. (a-e G.V. Somner et al. 611; f G. V. Somner et al. 1091; g-j G. V. Somner \& M. S. Ferrucci 1174; k G. V. Somner \& M. S. Ferrucci 1072).

Figure 4 - a-f. Serjania cuspidata Cambess. - a. vegetative branch; b. cross section of compound stem; c. staminate flower; d. posterior petal with appendage; e. anterior petal with appendage; f. samaroids mericarps. g-k. Serjania dentata (Vell.) Radlk. - g. vegetative branch; $h$. cross section of simple stem; i. posterior petal with appendage; $j$. anterior petal with appendage; k. Samaroids mericarps. 1-p. Serjania eucardia Radlk. - 1. biternate leaf; m. cross section of simple stem; n. posterior petal with appendage; o. anterior petal with appendage; p. fruiting branch. (a-e G.V. Somner et al. 611; f G. V. Somner et al. 1091; g-j G. V. Somner \& M. S. Ferrucci 1174; k G. V. Somner \& M. S. Ferrucci 1072). 
assimétrica, ápice agudo a acuminado, margem repando-denteada, 1-2 dentes no ápice. Tirso simples ou composto, racemiforme, pubérulo, pedúnculo $0,5-7 \mathrm{~cm}$, raque $0,8-9,8 \mathrm{~cm}$; bractéolas 0,5-0,7 mm compr., deltóides, glabrescentes, ciliadas; pedicelos 2-3,5 mm. Flores 5-7,5 mm compr.; sépalas 5, externas 2,7-3,9 mm, glabras e internas 3-3,8 mm, obovadas, margem ciliada, incano-velutinas; pétalas 2,8-3,6 mm compr., branco-amareladas obovadas, ciliadas; crista dos apêndices das pétalas posteriores bicorniculada, amarelada; lobos nectaríferos posteriores suborbiculares e anteriores menores; androginóforo glabro; flor estam. com androceu excêntrico, estames de 1,5-3 mm, pubescentes; pistilódio trígonoovóide, ca. 0,6 mm compr., glabro; flor pist. com gineceu de ca. 4,5 mm compr., excêntrico, ovário trígono-obovóide, 3-carpelar, 3-locular, 1 óvulo por lóculo, com tricomas glandulosos, estilete 1,3-1,7 $\mathrm{mm}$, estigma trífido, estaminódios 1,6-2,5 mm, pubescentes. Mericarpos samaróides 3, ovado-cordados, 2,5-3,2×2-2,7 cm, cartáceos, glabros, lóculos no ápice, ao nível dos lóculos 1,2-1,6 cm larg., porção seminífera do mericarpo com lóculos lenticulares, pouco inflados, base do lóculo arredondada, às vezes com crista dorsal, com 1-2 mm larg., alas descendentes; epicarpo glabrescente e endocarpo glabro; sementes 3, trígono-elipsóides, castanhas, 0,3-0,6×0,4-0,5 $\mathrm{cm}$, inseridas na base do lóculo; embrião 3,54,5 × 3-4 mm, cotilédone externo curvo e interno biplicado.

Nome popular: timbó-das-restingas.

Material selecionado: BRASIL, RIO DE JANEIRO: Mangaratiba, Restingas da Marambaia, Praia do Sino, 7.VII.1993, fr., G. V. Somner \& A. Ururahy 767 (RBR); Praia do Catuca, 7.III.1999, fl., M. C. Souza 109 (RBR). Rio de Janeiro, entrada próxima à Barra de Guaratiba, no Campo de provas do Exército, linha 2, estrada ao lado do posto velho da Marinha, 26.VII.2003, fr., G. V. Somner et al. 1103 (RBR).

Material adicional examinado: BRASIL, ESPÍRITO SANTO: Presidente Kennedy, Praia das Neves, 25.II.1989, fl. fr., J. M. L. Gomes 908 (RBR). RIO DE JANEIRO: Restinga de Grumari, 24.II.1972, fl., J. Almeida 1325(RB). Saquarema, Reserva Ecológica Estadual de Jacarepiá, margem da estrada, na floresta de cordão arenoso, 13.VIII.1992, fr., $G$. V. Somner et al. 753 ( RBR).

Distribuição e fenologia: Ocorre nos estados do Espírito Santo, Minas Gerais, Rio de Janeiro e São Paulo. Na Restinga da Marambaia é muito frequente na formação arbustiva fechada de cordão arenoso e na floresta de cordão arenoso. Coletada com flores em março e com frutos em julho.

12. Serjania eucardia Radlk., Consp. Sect. Sp. Serjania 5. $1874 . \quad$ Fig. 41-p

Trepadeira lenhosa, velutino-pubescente, monóica; com ramos floríferos castanhoescuros, 5-6-costados, com tricomas glandulares e simples, caule em seção transversal sinuoso-crenado, fistuloso, simples. Folhas biternadas; estípulas 1-2,5 mm, ovadolanceoladas, pubescentes; pecíolo 1,4-5 cm; raque nua; folíolos largo-subromboidais, ovados ou lanceolados, 2,4-8 × 1,3-4,8 cm, membranáceos, discolores, ambas as faces denso-velutino-pubescentes, a adaxial com tricomas glandulares, base aguda a atenuada, ápice acuminado a cuspidado, margem serreado-denteada, ciliada. Tirso simples ou composto, pedúnculo $2,5-15,3 \mathrm{~cm}$, raque $1,1-$ $7,5 \mathrm{~cm}$; bractéolas ca. $1 \mathrm{~mm}$, ovado-lanceoladas, pubescentes; pedicelos 3,5-4,5 mm. Flores 0,81,25 cm, brancas; sépalas 5, externas 2,5-3,5 $\mathrm{mm}$, internas 3,5-5 mm, ovadas, pubérulas, margem ciliada; pétalas 5-6,25 mm, obovadas; crista dos apêndices das pétalas posteriores emarginada; lobos nectaríferos 4, posteriores orbiculares, anteriores menores; androginóforo glabro; flor estam. com androceu excêntrico, estames 2-5,5 $\mathrm{mm}$, pouco piloso; anteras glandulosas; pistilódio trígono-obovóide, 1-1,5 $\mathrm{mm}$, glabro; flor pist. com gineceu 7-7,7 mm compr., excêntrico, ovário trígono-obovóide, 3carpelar, 3-locular, 1 óvulo por lóculo, ferrugíneo-glandulosos; estilete 1-1,4 mm, estigma trífido, estaminódios 2,6-4 $\mathrm{mm}$. Mericarpos samaróides 3, largo-ovadocordados, 3,2-5 ×2,8-4,4 cm., lóculos no ápice, alas descendentes, ápice truncado, cartáceos, ao nível dos lóculos 1,6-2,4 cm larg., porção seminífera do mericarpo com lóculos pouco 
inflados, com crista dorsal 2-5 mm, epicarpo pubérulo, com tricomas glandulares; endocarpo viloso, especialmente na margem do lóculo; sementes 3 , obovóides, achatadas lateralmente, $0,5-0,7 \times 0,4-0,6 \mathrm{~cm}$, inseridas na base do lóculo; embrião 4,5-6 mm compr., globoso, cotilédone externo curvo e interno biplicado.

Material selecionado: BRASIL, RIO DE JANEIRO: Restinga da Marambaia, entrada próxima à Praia da Barra de Guaratiba, no Campo de Provas do Exército: trilha em frente à Guarita, na formação arbustiva fechada de cordão arenoso, em frente à Estação Meteorológica desativada, 15.X.2002, fr., G. V. Somner $1072 \&$ M. S. Ferrucci (RBR); Ibidem, 10.IV.2005, fl., G. V. Somner \& M. S. Ferrucci 1174 (RBR).

Material adicional examinado: BRASIL, RIO DE JANEIRO: Cabo Frio, Arraial do Cabo, 19.II.1953, fl., H. Monteiro 4118 (RBR); Maricá, Ponta do Fundão, 24.II.1983, fl., G. V. Somner 342 (RBR).

Distribuição e fenologia: Ocorre nos estados da Bahia, Ceará, Pernambuco e Rio de Janeiro. No Rio de Janeiro ocorre tanto nas restingas como na floresta ombrófila densa. Na Restinga da Marambaia ocorre na formação arbustiva fechada de cordão arenoso. Coletada com flores em abril e com frutos em outubro.

13. Serjania ichthyoctona Radlk. Consp. Sect. Sp. Serjania 11. $1874 . \quad$ Fig: 5 a-e

Trepadeira lenhosa, latescente, monóica; ramos floríferos 3-costados, triangulares, costas proeminentes, glabros, caule composto formado por um cilindro central maior e 3 periféricos menores bastante proeminentes nos ângulos. Folhas biternadas; estípulas ca. 0,5 $\mathrm{mm}$, triangulares, glabras; pecíolo 1,5-10 cm, canaliculado, esparso-pubescente; raque marginada; folíolos ovados ou elípticos, 4,1$8,2 \times 1,6-4 \mathrm{~cm}$, coriáceos, base aguda, obtusa ou longamente atenuada, ápice obtuso ou acuminado, margem inteira e subrevoluta, ambas as faces glabras. Tirso simples ou composto, pedúnculo $0,2-2 \mathrm{~cm}$, glabro, raque 0,6-7,6 cm, tomentosa; bractéolas ca. $0,5 \mathrm{~mm}$ compr., deltóides, tomentosas; pedicelos 0,5$3 \mathrm{~mm}$. Flores $0,4-0,7 \mathrm{~cm}$, sépalas 5, tomentosas, margem ciliada, as externas $2-2,5 \mathrm{~mm}$ compr., ovadas, as internas 2,7-3 mm compr., oblongoovados; pétalas 3,2-4 mm compr., brancoesverdeadas, obovadas, crista dos apêndices das pétalas posteriores bicorniculada; lobos nectaríferos posteriores ovóides, anteriores menores; flor estam. com androceu excêntrico, estames 2-4 mm, pubescentes; pistilódio ca. 0,7 $\mathrm{mm}$ compr., trígono-ovóide; flor pist. com gineceu 3,5-4 mm compr., excêntrico; ovário trígono-obovóide, pubescente, 3-carpelar, 3locular, 1 óvulo por lóculo, estilete $0,5-0,75 \mathrm{~mm}$, estigma trífido, estaminódios $2-2,5 \mathrm{~mm}$, pubescentes. Mericarpos samaróides 3, 2,2$2,8 \times 1,8-2,3 \mathrm{~cm}$, lóculos no ápice, alas descendentes, cartáceos, ao nível dos lóculos 0,7-1 cm larg., porção seminífera do mericarpo globosa, quando jovem pubescente, adulto glabrescente, com nervuras proeminentes; alas e endocarpo glabros; sementes 3, obovóides, $0,5-0,6 \times 0,3-0,4 \mathrm{~cm}$, inseridas na base do lóculo, testa lisa, castanho-avermelhada; embrião $5 \times$ 3,5-4,5 mm, subgloboso; cotilédones subretos. Nomes populares: timbó ou timbó-de-peixe. Material selecionado: BRASIL, RIO DE JANEIRO: Mangaratiba, Restingas da Marambaia, Praia da Armação, 20.V.2003, L. F. T. Menezes 1088, est. (RBR); Praia Grande 23.VII.1991, fl., G. V. Somner et al. 645 (RBR).

Material adicional examinado: BRASIL, RIO DE JANEIRO: Mangaratiba, Ilha da Marambaia, margem direita da estrada que vai para a Praia da Armação, muito depois da entrada da Gruta da Santa, 16.IX.1993, fr., G. V. Somner et al. 781 (RBR); Ibidem, 31.VII.1997, fl., G. V. Somner \& M. S. Ferrucci 831 (RBR). Saquarema, Reserva Ecológica Estadual de Jacarepiá, margem da estrada, na floresta de cordão arenoso, 26.VIII.1991, fl., G. V. Somner \& M. F. Freitas 655 (RBR); Ibidem, 29.X.1991, fr., G. V. Somner et al. 702 (RBR).

Distribuição e fenologia: Ocorre nos estados da Bahia, Pernambuco e Rio de Janeiro. Encontrada na Restinga da Marambaia na floresta de cordão arenoso, mas pode estenderse da restinga até a região de interseção com a floresta ombrófila densa submontana, em região degradada, bastante ensolarada, constituída de solo argiloso-arenoso, chegando a aproximadamente $200 \mathrm{~m} \mathrm{~s}$. m. Coletada com flores em julho. 


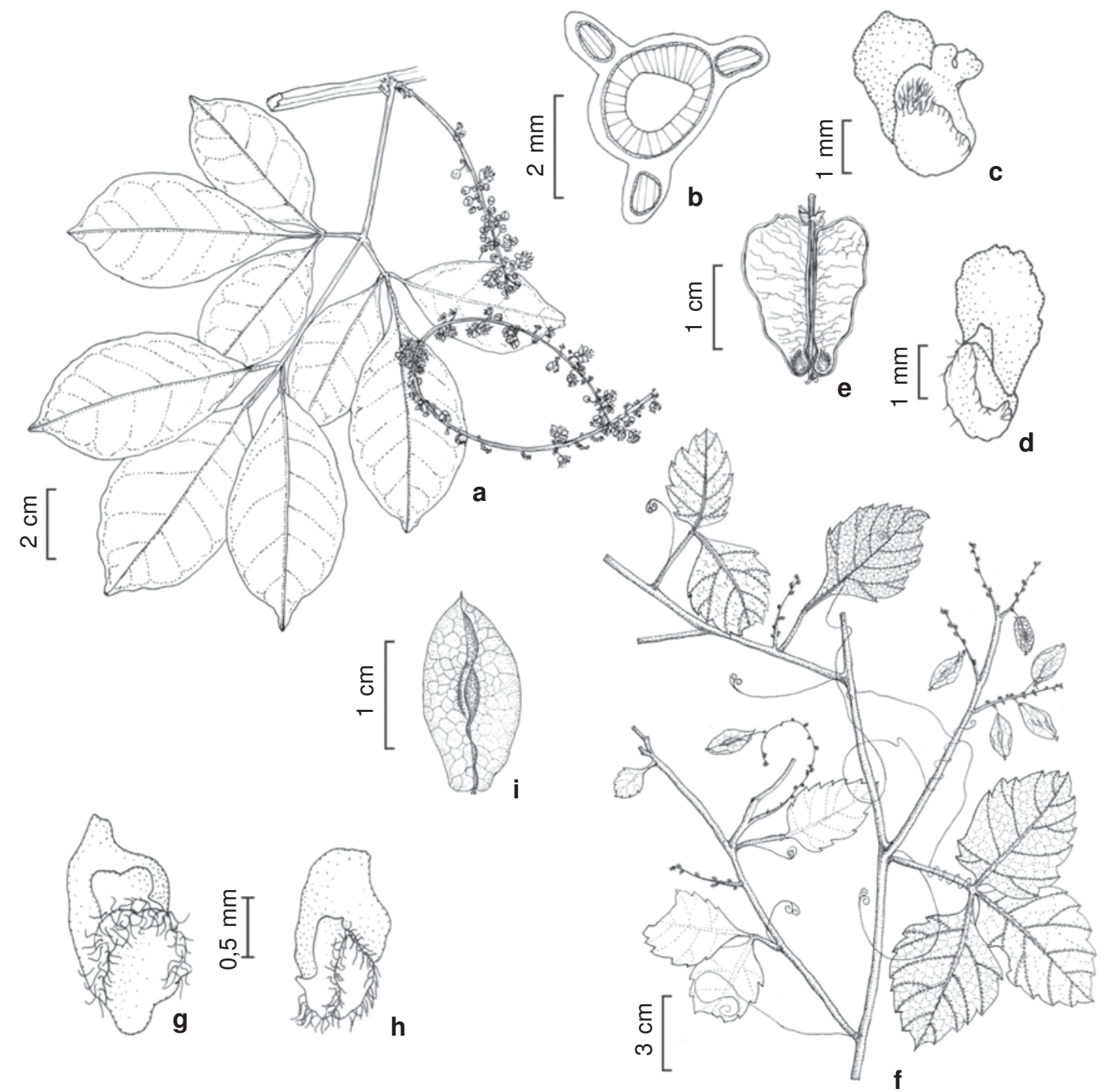

Figura 5 -a-e. Serjania ichthyoctona Radlk. - a. ramo florífero; b. seção transversal do caule composto; c. pétala posterior com apêndice; d. pétala anterior com apêndice; e. mericarpos samaróides. f-i. Urvillea rufescens Cambess. - f. ramo frutífero; g. pétala posterior com apêndice; h. pétala anterior com apêndice; i. cápsula septífraga trialada. (a-d G. V. Somner \& M. S. Ferrucci 831; e G. V. Somner et al. 702; f G. V. Somner et al. 710; g-h G. V. Somner et al. 803; i G. V. Somner et al. 710).

Figure 5 - a-e. Serjania ichthyoctona Radlk. - a. flowering branch; b. cross section of compound stem; c. posterior petal with appendage; d. anterior petal with appendage; e. samaroids mericarps. f-i. Urvillea rufescens Cambess. - f. fruiting branch; g. posterior petal with appendage; h. anterior petal with appendage; i. three-winged septifragal capsule. (a-d G. V. Somner \& M. S. Ferrucci 831; e G. V. Somner et al. 702; f G. V. Somner et al. 710; g-h G. V. Somner et al. 803; i G. V. Somner et al. 710)

14. Urvillea rufescens Cambess. in St.-Hil., Fl. Bras. Merid. 1: 354. $1828 . \quad$ Fig. 5 f-i

Trepadeira lenhosa, monóica; ramos floríferos jovens 5-6 costados, adultos cilíndricos, estriados, caule simples; estípulas, pecíolo, raque e eixo da inflorescência pubescentes, com tricomas glandulosos. Folhas 3-folioladas; estípulas $0,5-1 \mathrm{~mm}$ compr., triangulares, densamente pubescenteamareladas, com tricomas glandulares; pecíolo 1-4,2 cm, canaliculado; folíolos ovados ou ovado-subromboidais, $1,8-5,9 \times 1,3-3,6 \mathrm{~cm}$, subcoriáceos, discolores, subsésseis, base decorrente, truncada, arredondada, ápice acuminado, arredondado, mucronado, margem crenado-denteada, ciliada, pubescente nas 
nervuras da face adaxial e com tricomas glandulares alaranjados, pubescente na face abaxial. Tirso simples ou composto, axilar ou terminal, espiciforme, tomentoso, pedúnculo $0,2-5,3 \mathrm{~cm}$, raque $1,2-5,4 \mathrm{~cm}$; bractéolas $0,5-$ $1 \mathrm{~mm}$, deltóides, pubescentes; pedicelos ca. 0,5 $\mathrm{mm}$. Flores 2,5-3,5 mm, zigomorfas; sépalas 5 , livres, ciliadas, tricomas glandulosos em ambas as faces e na margem, externas ovadas, ca. $1 \mathrm{~mm}$, internas obovadas, $1,7-2 \mathrm{~mm}$; pétalas 4, branco-amareladas, 1,25-2 $\mathrm{mm}$; crista dos apêndices das pétalas posteriores emarginada, apêndices com margem vilosa; 4 lobos nectaríferos, 2 posteriores ovóides e 2 anteriores orbiculares, menores; androginóforo glabro; flor estam. com androceu excêntrico, estames 1,25-2,25 mm, glabros; pistilódio trigono-ovóide, ca. $1 \mathrm{~mm}$ compr., pubescente. flor pist. com gineceu ca. 2,25 mm compr., excêntrico, ovário trígono-elipsóide, pubescente, 3-carpelar, 3-locular, 1 óvulo por lóculo, estilete ca. $0,25 \mathrm{~mm}$, ginobásico, estigma trilobado, glanduloso, estaminódios 1,5-1,75 $\mathrm{mm}$, glabros. Cápsula 3-alada, inflada na porção central dos lóculos, com alas tão largas quanto 2-4 vezes a largura do lóculo, castanhoclara, elipsóide ou obovóide, 1,8-2,3×1-1,6 cm, estípite $0,5-1,25$, membranácea, ciliada, estilete persistente; epicarpo pubescente, endocarpo pubérulo; sementes 3 , elipsóides, achatadas lateralmente, $0,3-0,4 \times 0,2-0,4 \mathrm{~cm}$, com arilo seco cordiforme, testa castanho-avermelhada, levemente rugosa; embrião 3-3,5 × 2-3 mm, elipsóide; cotilédone externo curvo e interno biplicado.

Material selecionado: BRASIL, RIO DE JANEIRO: Mangaratiba, Restingas da Marambaia, caminho para a Praia da Gaeta, 29.V.2004, fl., L. F. T. Menezes et al. 1237 (RBR); Praia Grande, 23.VII.1991, fl., G. $V$. Somner 646 (RBR). Rio de Janeiro: entrada próxima à Praia da Barra de Guaratiba, Campo de Provas do Exército, Próximo à Guarita, quase em frente à casa PNR 48, na margem da estrada, 15.X.2002, fl. fr., G. V. Somner et al. 1073 (RBR).

Material adicional examinado: BRASIL, RIO DE JANEIRO: Mangaratiba; Ilha da Marambaia, margem direita da estrada que vai para a Praia da Armação, região de transição entre a restinga e a floresta ombrófila densa submontana, 24.IX.1991, fr., G. V. Somner et al. 674 (RBR). Saquarema: Reserva Ecológica Estadual de Jacarepiá, na mata de Ipitangas, na margem da estrada, floresta de cordão arenoso, 29.X.1991, fr., G. V. Somner et al. 710 (RBR); Ibidem, 31.VIII.1996, fl., G. V. Somner et al. 803 (RBR).

Distribuição e fenologia: Ocorre nos estados da Bahia, Minas Gerais, São Paulo e Rio de Janeiro. Na Restinga da Marambaia ocorre em floresta inundável e em formação arbustiva fechada de cordão arenoso. Coletada com flores de maio a julho e outubro, com frutos em outubro.

Assemelha-se muito à Urvillea ulmacea Kunth pelo número de folíolos, forma das folhas e inflorescência, mas difere desta por apresentar folíolos subcoriáceos, com margem crenado-denteada e face adaxial com venação conspícua, crista dos apêndices das pétalas posteriores emarginada.

\section{Agradecimentos}

Ao comando do Centro de Avaliação do Exército (CAEx) e ao Centro de Adestramento da Ilha da Marambaia (CADIM - Marinha do Brasil) pelo apoio logístico durante as atividades de campo. Ao Herbário RBR, da Universidade Federal Rural do Rio de Janeiro. À Fundação de Amparo à Pesquisa do Estado do Rio de Janeiro (FAPERJ) pela bolsa de iniciação científica concedida à Clarice Tavares Siqueira (Processo E26 151.216.2004).

\section{REFERÊNCIAS BIBLIOGRÁFICAS}

Araujo, D. S. D. 2000. Análise florística e fitogeográfica das restingas do estado do Rio de Janeiro. Tese de Doutorado. Universidade Federal do Rio de Janeiro, Rio de Janeiro. 184p.

Araujo, D. S. D. \& Maciel, N. C. 1998. Restingas fluminenses: biodiversidade e preservação. Boletim FBCN 25: 27-51.

Beck, H. T. 1990. A survey of the useful species of Paullinia L. (Sapindaceae). Advances in Economic Botany 8: 41-56.

Conde, M. M. S.; Lima, H. R. P. \& Peixoto, A. L. 2005. Aspectos florísticos e 
vegetacionais da Marambaia, Rio de Janeiro, Brasil. In: Menezes, L. F. T.; Peixoto, A. L. \& Araujo, D. S. D. História Natural da Marambaia. EDUR, Seropédica. Pp. 133-168.

Conde, M. M. S.; Silva, I. M.; Somner, G. V. \& Silva, D. 1995. Flora apícola da área em torno da Represa de Ribeirão das LajesRio de Janeiro. Revista da Universidade Rural, Série Ciências da Vida 172: 41-48.

Corrêa, M. P. \& Penna, L. A. 1952. Dicionário das plantas úteis do Brasil e das exóticas cultivadas. V. 3. IBDF, Rio de Janeiro. 346p.

Corrêa, M. P. \& Penna, L. A. 1975. Dicionário das plantas úteis do Brasil e das exóticas cultivadas. V. 6. IBDF, Rio de Janeiro. 777p.

Fraga, C. N.; Kollmann, L. J. C. \& Menezes, L. F. T. 2005. Orchidaceae da Restinga da Marambaia, Rio de Janeiro, RJ. In: Menezes, L. F. T.; Peixoto, A. L. \& Araujo, D. S. D. História Natural da Marambaia. EDUR, Seropédica. Pp. 121-132.

Ferrucci, M. S. 1991. Sapindaceae. In: Spichiger, R. Flora del Paraguay. Conservatoire et Jardin Botaniques de la Ville de Genève \& St. Luis, Missouri Botanical Garden, Ville de Genève, v. 16, Pp. 1-144, fig. 1-51.

Góes, M. H. B.; Silva, J. X.; Rodrigues, A. F.; Cavalcante, M. S. G.; Roncaratti, H.; Cravo, C. D.; Menezes, L. F. T.; Anjos, L. H. C.; Valadares, G. S. \& Pereira, M. G. 2005. Modelo digital para a Restinga e Paleoilha da Marambaia, Rio de Janeiro. In: Menezes, L. F. T.; Peixoto, A. L. \& Araujo, D. S. D. História Natural da Marambaia. EDUR, Seropédica. Pp. 231-284.

Köppen, W. 1948. Climatologia. Ed. Fundo de Cultura Econômica, Buenos Aires, México. 478p.

Lobão, A. Q.; Araujo, D. S. D. \& Kurtz, B. C. 2005. Annonaceae das restingas do estado do Rio de Janeiro, Brasil. Rodriguésia 56(87): 85-96.

Mattos, C. C. L. V. 2005. Caracterização climática da Restinga da Marambaia, RJ. In: Menezes, L. F. T.; Peixoto, A. L. \& Araujo, D. S.
D. História Natural da Marambaia. EDUR, Seropédica. Pp. 55-66.

Menezes, L. F. T. \& Araujo, D. S. D. 2005. Formações vegetais da Restinga da Marambaia, Rio de Janeiro. In: Menezes, L. F. T.; Peixoto, A. L. \& Araujo, D. S. D. (eds.). História Natural da Marambaia. EDUR, Seropédica. Pp. 67-120.

Menezes, L. F. T.; Peixoto, A. L. \& Araujo, D. S. D. 2005. História natural da Marambaia. EDUR, Seropédica. 288p.

Mori, S. A.; Silva, L. A.; Lisboa, G. \& Coradin, L. 1985. Manual de manejo do herbário fanerogâmico. CEPLAC, Itabuna. 97p.

Nunes-Freitas, A. F.; Rocha-Pessoa, T. C.; Cogliatti-Carvalho, L. \& Rocha, C. F. D. 2006. Bromeliaceae da restinga da Reserva Biológica Estadual da Praia do Sul: composição, abundância e similaridade da comunidade. Acta Botanica Brasilica 20(3): 709-717.

Oliveira-Filho, A. S.; Senna, L. M.; Pena, E. M. \& Alves, M. V. S. 1989. Euphorbiaceae Juss. - espécies ocorrentes nas restingas do estado do Rio de Janeiro, Brasil. Acta Botanica Brasilica 3: 131-139.

Peixoto, A. L. \& Thomas, W. W. 2005. Listas florísticas, floras regionais e flora do Brasil: desafios e estratégias. Centro de Referência em Informação Ambiental, Campinas. Disponível em: <http://www.cria.org.br/ cgee/documentos/Flora.doc $>$ Acesso em 25/05/2009.

Pereira, J. F.; Araujo, D. S. D. \& Paixão, R. J. 1997. Asclepiadaceae da Área de Proteção Ambiental de Massambaba. Pabstia 8(4): 1-16.

Radford, A. E.; Dickison, W. C.; Massey, J. R. \& Bell, C. R. 1974. Vascular plant systematics. Harper and Row Publishers, New York. 891p.

Radlkofer, L. 1892-1900. Sapindaceae. In: Martius, C. F. P. \& Eichler, A. G. Flora brasiliensis. Frid. Fleischer, Lipsiae, 13(3): 225-658, tab. 58-123.

Radlkofer, L. 1931-1934. Sapindaceae. In: Engler, A. Das Pflanzenreich. Wilhelm 
Engelmann, Leipzig, IV-165, Heft 98ah, f. 1-46. Pp. 1-1539.

Reis, R. C. C. 2006. Palmeiras (Arecaceae) das restingas do estado do Rio de Janeiro, Brasil. Acta Botanica Brasilica 20(3): 501512.

Reitz, R. 1980. Sapindáceas. In: Reitz, R. Flora Ilustrada Catarinense. Herbário Barbosa Rodrigues, Itajaí. 156p.

Roncarati, H. \& Menezes, L. F. T. 2005. Marambaia, Rio de Janeiro: origem e evolução. In: Menezes, L. F. T.; Peixoto, A. L. \& Araúuo, D. S. D. História natural da Marambaia. EDUR, Seropédica. Pp. 15-38.

Sá, C. F. C. 1992. A vegetação da Restinga de Ipitangas, Reserva Ecológica Estadual de Jacarepiá, Saquarema (RJ), fisionomia e listagem das Angiospermas. Arquivos do Jardim Botânico do Rio de Janeiro 31: 87-102.

Segadas-Vianna, F.; Ormond, W. T. \& Dau, L. 1965-1978. Flora ecológica de restingas do sudeste brasileiro. 23 v. Museu Nacional, Rio de Janeiro.
Silva, J. G. \& Oliveira, A. S. 1989. A vegetação de restinga no município de Maricá, RJ. Acta Botanica Brasilica 3 (2): 253-272.

Somner, G. V. 2001. Sapindaceae. In: Costa, A. F. \& Dias, I. C. A flora do Parque Nacional da Restinga de Jurubatiba e arredores, Rio de Janeiro, Brasil: Listagem, florística e fitogeografia. Série Livros, n. 8. Museu Nacional, Rio de Janeiro. Pp. 126-128.

Souza, M. C. \& Morim, M. P. 2008. Subtribo Eugeniinae O. Berg. e Myrtinae O. Berg (Myrtaceae) na Restinga da Marambaia, RJ, Brasil. Acta Botanica Brasilica 22 (3): 652-683.

Souza, M. C.; Morim, M. P.; Conde, M. M. S. \& Menezes, L. F. T. 2007. Subtribo Myrcinae O. Berg. (Myrtaceae) na Restinga da Marambaia, RJ, Brasil. Acta Botanica Brasilica 21 (1): 49-63.

Weberling, F. 1989. Morphology of flowers and inflorescences. Cambridge University Press, Cambridge. 405p. 